Article (refereed)

Smith, J.T.; Walker, L.A.; Shore, R.F.; Durell, S.E.A. Le V. dit; Howe, P.D.; Taylor, M.. 2009 Do estuaries pose a toxic contamination risk for wading birds? Ecotoxicology, 18 (7). 906-917. 10.1007/s10646-009-0352-z

๑) Springer Science+Business Media LLC 2009

This version available http://nora.nerc.ac.uk/7676/

NERC has developed NORA to enable users to access research outputs wholly or partially funded by NERC. Copyright and other rights for material on this site are retained by the authors and/or other rights owners. Users should read the terms and conditions of use of this material at http://nora.nerc.ac.uk/policies.html\#access

This document is the author's final manuscript version of the journal article, incorporating any revisions agreed during the peer review process. Some differences between this and the publisher's version remain. You are advised to consult the publisher's version if you wish to cite from this article.

www.springerlink.com 
Appeared as: Smith, J.T., L A Walker, L.A., Shore, R.F., Durell, S E A le V, Howe, P.D., Taylor, M. (2009). Do estuaries pose a toxic contamination risk for wading birds? Ecotoxicology, Vol 18, No. 7, 906-917.

\section{Do estuaries pose a toxic contamination risk for wading birds?}

J T Smith ${ }^{a^{*}}$, L A Walker ${ }^{\text {b }}$, R F Shore ${ }^{\text {b }}$, S E A le V dit Durell ${ }^{\mathrm{c}}$, P D Howe ${ }^{\mathrm{d}}$, M Taylor ${ }^{\mathrm{e}}$.

a. School of Earth and Environmental Sciences, University of Portsmouth, Burnaby Building, Portsmouth PO1 3QL. * Corresponding author: E-mail: jim.smith@port.ac.uk; Tel. +44 (0)2392 842416; Fax: +44 (0)2392842244.

b. NERC Centre for Ecology \& Hydrology, Lancaster Environment Centre, Library Avenue , Bailrigg, Lancaster LA1 4AP, UK

c. 30 Bestwall Road, Wareham, Dorset BH20 4JA, UK

d. Centre for Ecology and Hydrology, Monks Wood, Abbots Ripton, Huntingdon, Cambridgeshire, PE28 2LS, UK

e. Natural England, Riverside Chambers, Castle Street, Taunton, Somerset, TA1 4AP 


\begin{abstract}
The impact of potentially toxic chemicals on wildlife is commonly assessed by comparing the intake of the contaminant with the "no observable effects level" (NOAEL) of intake. It is known, however, that there are considerable uncertainties inherent in this method. This study presents a Monte-Carlo based model to assess the degree of risk posed to birds (dunlin, Calidris alpina) from important estuarine habitats, and to show the limitations of such risk assessments, particularly with regard to data availability. The model was applied to predict the uptake of metals $(\mathrm{Hg}, \mathrm{Pb})$ in this shorebird species in Poole Harbour and the Severn Estuary/Bristol Channel, UK, two internationally important shorebird habitats. The results show that in both areas, $\mathrm{Pb}$ and $\mathrm{Hg}$ concentrations may pose an ecologically-relevant toxic risk to wading birds. For $\mathrm{Pb}$, uncertainty in NOAEL values dominates the overall uncertainty. Use of lethal toxicity data (LD50/100) was investigated as a method for assessing sub-lethal impacts from $\mathrm{Hg}$. It was found that this method led to a significant under-estimate of the potential impact of $\mathrm{Hg}$ contamination, compared with direct estimation of NOAEL.
\end{abstract}

Key words: mercury, lead, probabilistic modelling, estuaries, reproductive toxicity, dunlin. 


\section{INTRODUCTION}

3 Analysis of uncertainty in environmental risk assessments is becoming increasingly important

4 (e.g. Verdonck et al., 2005). To our knowledge, however, modelling approaches have not yet

5 been developed for the assessment of uncertainty in contaminant uptake and risk in wading

6 birds. Here we present a probabilistic modelling approach for risk assessment that employs

7 ecologically relevant toxicological endpoints and, crucially, data inputs (bird behaviour,

8 metal content of prey items, toxicity endpoints) that are realistic for typical environmental

9 impact assessments. The Monte-Carlo based model is used to assess the degree of risk posed

10 to birds from important estuarine habitats, and to show the limitations of such risk

11 assessments, particularly with regard to data availability.

13 Estuaries are typically important feeding areas for wading birds but are also often subject to

14 historic and current chemical contamination by heavy metals. Estuarine sediments

15 commonly form major sinks for contaminants released during industrial activity. Many

16 industrial processes lead to the release of metals initially in solution, which can then be

17 adsorbed on to, for example, Fe hydroxides or clay minerals (Pirrie et al., 2003) and are subsequently deposited onto estuarine sediments. Both past mining activity and present industrial discharges have resulted in the accumulation of metals in estuarine sediment.

21 The Severn Estuary/Bristol Channel and Poole Harbour (Figure 1) are two major UK

22 estuaries and are classified as Special Protection Areas (SPAs) under the European Wild

23 Birds Directive. During the winter, they support nationally and internationally important numbers of overwintering shorebirds (Pickess and Underhill-Day, 2002; Pollitt et al., 2003).

25 However, both areas are typical of estuaries in that they have previously been subject to

26 significant metal contamination. Much of the metal contamination has been adsorbed onto 
estuarine sediments and as a consequence concentrations of heavy metals in sediments usually exceed those of the overlying water by between three and five orders of magnitude.

With such high concentrations, the bioavailability of even a small fraction of the total sediment metal can lead to uptake by filter-feeding and burrowing organisms (Bryan and Langston, 1992). Furthermore, several metals, including mercury and lead, may be transformed in sediments to organometallic compounds which have greater bioavailability. These factors can result in accumulation of heavy metals by wading birds feeding in these areas (Bryan and Langston, 1992; Ferns and Anderson, 1997). Although there is evidence that metal contamination is declining in both Poole Harbour (Langston, 2003a) and the Severn Estuary (Duquesne et al., 2006; Langston et al., 2003b), the current levels of contamination suggest that they could still potentially have an impact on wildlife.

Assessment of the potential risk to wading birds posed from contamination has rarely been carried out, except where there have been specific spills or industrial incidents (Bull et al., 1983); (Pain et al., 1998). The aim of the current paper is to use the Severn Estuary and Poole Harbour as model systems (for which relatively good empirical data are available) to assess the potential risk posed to wading birds from long-term metal contamination in estuaries. A Monte Carlo analysis will be carried out to estimate the probability that the wading bird population is over-exposed to $\mathrm{Pb}$ and $\mathrm{Hg}$ in the two estuaries.

\section{METHODS}

The variability in population-averaged risk to dunlin, Calidris alpine, was assessed using a scenario approach. This species was selected because data on its diet selection and habitat 
scenarios: the 'Average' Scenario and the 'Worst Case' scenario. The 'Average' Scenario represents the best estimate and range of possible PPC/PNEC (predicted prey concentration/predicted no effect concentration in prey) values for the average bird, which is assumed (over a season) to have a dietary intake of contaminants equal to the mean concentration in prey across all the sites studied. The 'Worst Case' scenario assumes a juvenile bird (which has a lower ratio of body weight to food intake rate and hence a higher PPC/PNEC) feeding exclusively at the most contaminated site in each estuary.

For each of these scenarios, the uncertainty in predicted PPC/PNEC value was determined by Monte Carlo analysis after assigning uncertainties to each model input parameter based on evaluation of empirical data.

63

Selection of contaminants to be modelled

An initial screening exercise was carried out to determine which contaminants to focus on in subsequent modelling. This was carried out by calculating the Predicted Environmental Concentration (PEC) and the Predicted No Effect Concentration (PNEC) in birds for each contaminant. The PEC in this case was the predicted concentration of the contaminant in the prey of the birds and is in this paper termed the PPC. The ratio of the PPC to the PNEC was calculated as:

$$
\frac{P P C}{P N E C}
$$

where values of this ratio above 1 imply a toxic risk. A key prey item, ragworms (Nereis diversicolor), were sampled from 12 sites in Poole Harbour and 13 sites in the Severn Estuary (Environment Agency, unpubl. res.). It was assumed (for the purposes of the initial screening 
exercise only) that contaminant concentrations in Nereis diversicolor were representative of those in the range of different prey items in each estuary, though in the full uncertainty analysis below, other prey types (earthworms, molluscs and crustaceans) were also considered. Estimates of PPC/PNEC were made for each of the organic and inorganic contaminants measured in Nereis. The results of this screening exercise are presented in the Supplementary Material (Tables S1 and S2). Seven compounds (all metals or semi-metals) had maximum PPC/PNEC ratios $\geq 1$ : zinc $(\mathrm{Zn})$, lead $(\mathrm{Pb})$, mercury $(\mathrm{Hg})$, selenium $(\mathrm{Se})$, iron $(\mathrm{Fe})$, arsenic (As), and chromium $(\mathrm{Cr})$ for at least one of the sites. Fe was not determined in the Severn Estuary and Se was not determined in Poole Harbour. The source toxicity data used in calculating the screening PPC/PNEC ratios were then examined in detail to determine if they were experimentally sound (if they fulfilled the criteria set out in the Toxicity Data Section below) and if the endpoints were ecologically relevant. Using these criteria, only $\mathrm{Pb}$ and $\mathrm{Hg}$ were selected for subsequent detailed modelling.

\section{Model input data}

\section{Bird distribution and diet}

Bird habitat use and feeding behaviour were estimated using a combination of a foraging model which accounts for the different utilisation of feeding sites within an estuary (Stillman et al., 2005; Durell et al., 2006), the Wetland Bird Survey (WeBS) data and other literature data (Goss-Custard et al., 1988; Worrall, 1984). The proportion of different prey types taken by the birds and their associated uncertainty estimates are shown in Table 1. Earthworms comprise a significant part of the diet for some shorebird species, but in these estuaries dunlin do not consume significant proportions of earthworms in their diet. In Poole Harbour, dunlin have not been observed to eat earthworms (Durell et al., 2006), the major proportion of the 
102 diet of adult dunlin being marine worms, the rest being made up of molluscs and crustaceans.

103 In the Severn Estuary, earthworms are estimated to form less than $10 \%$ of their diet. Juvenile

104 dunlin (Table 1) take similar food types to adults.

105

106 Dietary lead and mercury concentrations

107 The data on $\mathrm{Pb}$ and $\mathrm{Hg}$ concentrations in Nereis diversicolor used in our model comprised

108 not only new measurements (Environment Agency, unpubl. res.)) but also data from reviews

109 of contamination in Poole Harbour and the Severn Estuary (Langston et al., 2003b),

110 Supplementary Material, Tables S3-S6). Assumed ranges and estimates of uncertainty in

111 metal concentrations used in the model are summarised in Table 2. For prey items other than

112 Nereis, uncertainties in metal concentrations were estimated from data in the reviews, taking

113 account of the known decline in metal contamination over time.

114

115 For the worst-case scenario, it was assumed that the mean concentration of $\mathrm{Pb}$ and $\mathrm{Hg}$ in

116 Nereis was equal to the highest value measured at any of the sites in each harbour with

117 uncertainty being normally distributed with coefficient of variation of $25 \%$. Based on the

118 review of data in Tables S3 - S6, for molluscs and crustaceans it was assumed (for the worst

119 case scenario) that the average concentration at the most contaminated site was 3-10 times

120 higher ( $\mathrm{Pb}, \mathrm{Hg}$ - Poole Harbour; $\mathrm{Pb}$ - Severn Estuary) or 1-3 times higher ( $\mathrm{Hg}$ - Severn

121 Estuary) than the maximum measured value in Nereis.

122

Metal concentrations in earthworms (Lumbricus terrestris)

124 Dunlin in Poole Harbour do not consume earthworms (Durell et al., 2006) and we assumed

125 that this was also true for most dunlin in the Severn Estuary (Table 1). Data on $\mathrm{Pb}$

126 concentrations in earthworms is limited but a study of the Avonmouth smelter found 
127 concentrations in worms at an unaffected site distant from the smelter to be $27 \mathrm{mg} \mathrm{kg}^{-1}$ (dw)

128 (Spurgeon, 1994). Concentrations in worms on a control site from a separate study were $4-$ $12.3 \mathrm{mg} \mathrm{kg}^{-1} \mathrm{dw}$ (Morgan and Morgan, 1991).

130 Concentrations of $\mathrm{Hg}$ in earthworms measured by (Bull et al., 1977) at a site uninfluenced by

131 industrial activity (range $0.031-0.048 \mathrm{mg} \mathrm{kg}^{-1} \mathrm{dw}, \mathrm{n}=18$ ) were generally lower than those 132 measured in estuarine biota (see Tables $\mathrm{S} 4$ and $\mathrm{S6}$ ). This suggests that, in contrast to $\mathrm{Pb}, \mathrm{Hg}$ 133 in earthworms may have little effect on $\mathrm{Hg}$ intake in shorebirds.

Proportion of dietary mercury as methylmercury

136 The NOAEL of methylmercury $(\mathrm{MeHg})$ is approximately two orders of magnitude lower than

137 that for inorganic $\mathrm{Hg}$. It is therefore important to estimate the proportion of total $\mathrm{Hg}$ in prey 138 items which is in the form of MeHg. Muhaya et al. (1997) determined that the mean 139 proportion of $\mathrm{Hg}$ as $\mathrm{MeHg}$ in Nereis across 13 sites in the Netherlands was approximately $14018 \%$, but the distribution of values was highly skewed. We therefore log-transformed these

141 data (mean $( \pm \mathrm{SD}) \log$ transformed proportion: $1.28 \pm 0.22)$ and used this transformed

142 distribution to generate random values for our Monte-Carlo model. The values were then 143 back-transformed for use in the model.

\section{Toxicity data}

146 A literature search was conducted to identify studies from which avian NOAELs could be

147 derived for inorganic and organic $\mathrm{Pb}$ and $\mathrm{Hg}$. We used Web of Knowledge (ISI, 2005),

148 Environmental Health Criteria (World Health Organisation, 1989a; World Health

149 Organisation, 1989b; World Health Organisation, 1990; World Health Organisation, 1991),

150 US EPA ECOTOXicology database (U.S. Environmental Protection Agency, 2002), and a

151 number of US EPA reports (Sample et al., 1997; U.S. Environmental Protection Agency, 
152 1999; U.S. Environmental Protection Agency, 2005) as reference sources. Where possible,

153 the original papers or reports were assessed, and three criteria were used to decide whether the

154 NOAEL values could be included in our models. These were:

155 (i) effects on reproduction and growth are more likely to affect population densities than

156 lower order effects and in some cases are the integrated response to a range of physiological

157 and biochemical effects. Thus, NOAELs based on reproduction and growth end-points were

158 included but those based on physiological, metabolic, biochemical and other lower level end-

159 points were rejected. This selection procedure also increased the likelihood of finding

160 sufficient toxicity data for our model as there were unlikely to be multiple studies that used

161 exactly the same physiological and biochemical endpoints.

162 (ii) use of only one NOAEL from a study when multiple NOAELs were derived from the same test, thereby avoiding pseudo-replication (when multiple NOAELs were derived in the same study but from different tests, all values were included).

165 (iii) studies in which the highest exposure level was assumed to be the NOAEL were excluded 166 because no effects were observed at any exposure level.

The value of a NOAEL and Lowest Observed Adverse Effect Levels (LOAELs) is partly determined by the experimental design of the study if, in the case of NOAELs, no effect is observed at the highest dose administered or, in the case of LOAELs, an effect is observed at

171 the lowest dose administered. Using NOAELs derived in such studies may give an over-

172 estimate of the toxicity of a contaminant while using LOAELs may under-estimate the toxicity. NOAELs were used in this study as a precautionary approach in assessing risk to wading birds. Even the studies reporting NOAELs for the effects of $\mathrm{Pb}$ and $\mathrm{Hg}$ on reproduction and growth are sparse in number. Therefore, we also included studies which

176 reported chronic Lowest Observed Adverse Effect Levels (LOAELs) for appropriate end- 
177 points and also investigated the use of LD50 values. Chronic LOAELs were divided by 10

178 and LD50s were divided by 100 to approximate them to chronic NOAELs, following

179 (USACHPPM, 2000).

180

181 The ranges in NOAEL used in our models are summarised in Table 3, and the individual data

182 are presented in Table S7 in the Supplementary Material: this table also gives information on

183 the species on which the tests were conducted. For $\mathrm{Pb}$, we found only four studies that met

184 our selection criteria for NOAELs. There are few avian lethality tests for inorganic $\mathrm{Pb}$ and,

185 for those test that have been done, LC50 values typically exceed the highest experimental

186 dose ( $\geq 5000 \mathrm{mg} \mathrm{Pb} / \mathrm{kg}$ food). Although we found two avian LD50 values for tetraethyl lead,

187 there appear to be large differences in toxicity between tetraethyl $\mathrm{Pb}$ and $\mathrm{Pb}$ salts and so we

188 did not use the data for tetraethyl $\mathrm{Pb}$ in our model. For $\mathrm{Hg}$, we found five values (two for

189 inorganic $\mathrm{Hg}$, three for Me-Hg) of chronic NOAELs. Seven further NOAELs (six for MeHg,

190 one for inorganic $\mathrm{Hg}$ ) were derived from LD50 values. For MeHg, there are LD50 values for

$191 \mathrm{Hg}$ for six species of bird (multiple values for most species). We calculated a geometric mean

$192 \mathrm{LD}_{50}$ for each species, then, divided these figures by 100 to convert them to chronic

193 NOAELs. The range of NOAELs derived in this way was 0.195 to $0.378 \mathrm{mg} \mathrm{kg}^{-1} \mathrm{day}^{-1}$, at

194 least one order of magnitude higher than experimentally-derived chronic NOAELs for methyl

195 mercury dicyandiamide based on reproductive end-points.

196

197 Modelling

198 The PPC/PNEC approach was used for the more detailed modelling of $\mathrm{Hg}$ and $\mathrm{Pb}$ impacts.

199 The PPC was predicted using:

200

$201 \quad P P C=\sum_{i} f_{i} C_{i}$ 
where $f_{i}$ is the fraction of the birds' diet composed of prey item $i$ and $C_{i}$ is the concentration

$204\left(\mathrm{mg} \mathrm{kg}^{-1} \mathrm{dw}\right)$ of the metal in prey item $i$.

206 The PNEC was estimated using

$$
\mathrm{PNEC}=\frac{\mathrm{NOAEL}(\mathrm{mg} / \mathrm{kg} \mathrm{BW} / \text { day }) \times \mathrm{BW}(\mathrm{kg})}{\text { FIR }(\mathrm{kg} \mathrm{DW} / \text { day })}
$$

where NOAEL is the no observable adverse effect level, BW is the bird body weight and FIR

211 is the average daily food intake rate. PPC/PNEC ratios are calculated on a dry weight basis. .

213 A Monte-Carlo model was programmed in Microsoft Excel using, where appropriate,

214 Microsoft Visual Basic macros. Using the available data, we ran the Monte-Carlo model to

215 estimate ranges in possible PPC/PNEC values. A total of 10000 random values were

216 generated for each variable. These were based on a normal (or lognormal, as appropriate)

217 distribution about a mean where data were available to determine the mean and uncertainty.

218 When there were insufficient data to estimate probability distributions, a uniform distribution

219 across the range in observed parameter values was assumed. An additional step was

220 introduced into the model for $\mathrm{Hg}$ which was to estimate the fraction of total $\mathrm{Hg}$ made up by

$221 \mathrm{MeHg}$. A model sensitivity analysis was carried out by first assigning to each of the input

222 parameters its mean value (c.f. Cox et al., 2006). Individual input parameters were then assigned random values within their uncertainty distributions for 10000 model runs to determine the impact of uncertainty in each input parameter on the predicted PPC/PNEC value. 
227 The daily food intake rate (FIR) was estimated using empirical relationships between food 228 intake rate and body weight (BW) (Nagy, 2001). For shorebirds, gulls and auks the daily food

229 intake (FIR; DW, $\mathrm{kg} \mathrm{d}^{-1}$ ) is estimated by regression from data for 15 species in $(\mathrm{Nagy}, 2001)$ 230 giving:

$\left(\mathrm{n}=15, \mathrm{R}^{2}=0.86, \mathrm{p}<0.001\right)$. The residuals in this model were approximately lognormally distributed with mean (of logged ratios model:measured) 0 and standard deviation (of logged ratios) 0.123 . The regression equation and distribution of residuals was used to determine the best estimate and uncertainty in FIR for dunlin.

\section{Results}

The model gives the probability distribution of estimated PPC/PNEC values based on 10000 model runs for each estuary and scenario. An example of the model output for $\mathrm{Pb}$ in Poole Harbour ('Average' Scenario) is shown in Figure 2, and for $\mathrm{Hg}$ in the Severn Estuary in

244 Figure 3. All of the model outputs were summarised as the median, $5^{\text {th }}$ and $95^{\text {th }}$ percentile 245 values of PPC/PNEC in Poole Harbour and the Severn Estuary (Table 4).

Lead

248 For the 'Average' Scenario, median PPC/PNEC values for Pb were 2.0 and 6.5 for Poole 249 Harbour and the Severn Estuary respectively (Figure 4). The lowest 5 percentile value was 250 less than 1 in both estuaries, but the highest 95 percentile values were 22 and 75 in Poole 251 Harbour and the Severn Estuary respectively. For the 'Worst Case' scenario, median 
PPC/PNEC values were only slightly higher than for the 'Average' Scenario; however, 95 percentile values were significantly higher, ranging up to 121 .

Mercury

PPC/PNEC estimates for both estuaries are shown in Figure 5. There were sufficient ecotoxicological data to compare the PPC/PNEC ratios for MeHg based either on experimentally-derived NOAELs or on the much higher approximated values calculated as LD50/100 (Table 3). The predicted PPC/PNEC ratios were much higher when based on experimentally derived NOAELs than when based on the LD50/100 (Figure 5). When the PNEC was estimated using the LD50/100, $\mathrm{Hg}$ would not be predicted to have any environmental impact on birds in either estuary, since PPC/PNEC values were lower than 1 (with a probability of $>95 \%$ ). In contrast, there is a significant (i.e. $>5 \%$ ) probability that PPC/PNEC values for $\mathrm{Hg}$ based on the experimentally derived NOAEL are greater than 1 in both Poole Harbour and the Severn Estuary. Nevertheless, PPC/PNEC values for $\mathrm{Hg}(18 \%$ $\mathrm{MeHg}$, based on NOAEL) are much lower than for $\mathrm{Pb}$ in Poole Harbour with the median PPC/PNEC being close to 1 for both 'Average' and 'Worst Case' scenarios.

\section{Sensitivity Analysis}

270

271 We have evaluated the sensitivity of the model to uncertainty in different input parameters.

272 Illustrative results of different sensitivity analyses are discussed here.

274 There is a very large uncertainty in the NOAEL for $\mathrm{Pb}$; this varies approximately uniformly

275 over a range spanning two orders of magnitude (Figure 6). As illustrated in Figure 6, this 276 uncertainty in NOAEL dominates the uncertainty in the PPC/PNEC ratio for $\mathrm{Pb}$ when all 
other parameters are assigned their mean value. The predicted PPC/PNEC ratio, when only

278 NOAEL varies, spans a similar range to that predicted when all parameters are allowed to vary. When the sensitivity analysis was carried out for other parameters (i.e. other individual

280 parameters varied whilst all other parameters assigned their mean) the variation in the

281 predicted PPC/PNEC was minor (Figure 6).

282

The sensitivity analysis for $\mathrm{Hg}$ is illustrated in Figure 7. The PPC/PNEC ratio for $\mathrm{Hg}$ is predicted with significantly greater certainty than that for $\mathrm{Pb}$ with predicted PPC/PNEC values for $\mathrm{Hg}$ being within a range of approximately one order of magnitude. The percentage of $\mathrm{Hg}$ in the form $\mathrm{MeHg}$ is the most important source of uncertainty in the predicted PPC/PNEC ratio, though uncertainty in Hg content of molluscs, FIR and NOAEL also contribute significantly to model uncertainty.

The outputs of the sensitivity analysis for different estuary scenarios showed very similar

291 patterns to the illustrative examples we have given for $\mathrm{Pb}$ and $\mathrm{Hg}$ in Figures 6 and 7

292 respectively.

\section{Discussion}

This assessment of two estuaries showed a potential impact of $\mathrm{Hg}$ and $\mathrm{Pb}$ contamination on

297 shorebird communities. For the Average Scenario, there was estimated to be a greater than

$29850 \%$ probability that PEC/PNEC values exceeded 1 for $\mathrm{Pb}$ in both estuaries and for $\mathrm{Hg}$ in the

299 Severn Estuary (Table 4). There was an approximately 40\% probability that PEC/PNEC

300 exceeded 1 for $\mathrm{Hg}$ in Poole Harbour. For the "Worst Case" scenario, probabilities of

301 PEC/PNEC > 1 were $95 \%$ or greater for both metals in the Severn Estuary and 68 and $75 \%$ 
302 for $\mathrm{Hg}$ and $\mathrm{Pb}$ (respectively) in Poole Harbour. For $\mathrm{Hg}$, where PNEC was calculated on the basis of LD50/100, PEC/PNEC values were not predicted to exceed 1 in either estuary (Table 4).

The study on two model estuaries for which relatively strong empirical data on shorebird

307 (dunlin) feeding habits and metal concentrations were available demonstrates that intakes of these metals in metal contaminated estuaries are at levels which may have adverse effects on ecologically-relevant endpoints. This conclusion is based on an assessment of the food uptake

310 pathway. We will, however, briefly consider the potential importance of other uptake

311 pathways for these metals.

Alternative Uptake Pathways

Because the water-prey bioaccumulation factor is high for these metals, the direct ingestion of water by birds is a much less important uptake pathway than the food pathway we have

317 modelled here. It therefore plays no significant role in predictions of PEC and uncertainty in 318 those predictions (Crane et al., 2005).

Uptake by ingestion of contaminated soil or sediment may occur incidentally (as, for example, soil or sediment attached to food is ingested) or deliberately (some birds, for example, deliberately ingest grit). Ingestion of contaminated soil or sediment is likely to vary significantly depending on the behaviour and diet of a bird. For different species of birds, the USEPA (USEPA, 1993) have estimated values of $<2 \%$ to $30 \%$ soil or sediment (per unit dry weight) in faeces of different birds. The highest values were observed in sandpipers which

326 feed on mud-dwelling invertebrates. 
328 Using data for $\mathrm{Pb}$ and $\mathrm{Hg}$ in sediments in Poole Harbour (taken from the same sites as Nereis were sampled; Environment Agency, unpubl. res.), we have estimated the potential uptake via contaminated sediments in comparison with direct uptake from food. The calculation assumed that either $2 \%$ of dry matter intake (DMI) is sediment, or $30 \%$ of DMI is sediment. This assumption is based on the USEPA (USEPA, 1993) study of sediment in faeces, though this is likely to be somewhat over-estimated since dry mass of excreted food is lower than dry mass of ingested food. For $\mathrm{Pb}$, the amount of ingested metal per day via sediment was in the range $0.01-0.15 \mathrm{mg} \mathrm{d}^{-1}$ (for DMI in the range 2-30\%) compared to $0.039 \mathrm{mg} \mathrm{d}^{-1}$ via food.

336 For $\mathrm{Hg}$, the ingestion rate via sediment was in the range $7.4 \times 10^{-5}$ to $1.1 \times 10^{-3} \mathrm{mg} \mathrm{d}^{-1}$ compared to $1.6 \times 10^{-3} \mathrm{mg} \mathrm{d}^{-1}$ via food. It should be noted, however, that: (1) the upper range of sediment ingestion rate of $30 \%$ may be unrealistically high: for sandpipers the range was estimated to be in the range 7.3-30\% (USEPA, 1993) and; (2) metals adsorbed to sediments may be less bioavailable than those in prey (Sheppard et al., 1995). It is, however, possible

341 that direct ingestion of sediment could lead to higher PPC/PNEC values than those

342 determined for the food pathway alone, although uncertainties in metal bioavailability and sediment uptake make the role of the sediment pathway difficult to quantify.

\section{Uncertainty in Model Predictions}

347 It should be noted that model sensitivity analyses, by definition, only give information on the

348 uncertainty encompassed within the defined model. A sensitivity analysis does not necessarily encapsulate all sources of uncertainty (a limitation of all environmental and ecological models). It is possible that due to unknown factors (which may make model parameters vary to a different extent than those assumed in the model) real PPC/PNEC values 
may be different to the predicted ranges. For example, the NOAEL values used for this study are necessarily estimated from data on laboratory birds of different species than those studied here. Actual NOAELs of the wild species studied here may be significantly different to those used in the model. Thus sensitivity analysis (whilst being a powerful modelling tool) cannot alone determine predictive uncertainty of environmental models.

\section{Reducing uncertainty}

Further field studies of metal concentrations in prey and (to the extent which it is possible) field assessments of the impact of metals on bird health/populations would be required to further reduce model uncertainty and to improve assessment of that uncertainty (i.e. validate predictions). For $\mathrm{Pb}$, as shown above, the uncertainty in NOAEL is the dominant factor in model sensitivity, so reducing this uncertainty will have a much greater impact than reducing uncertainty in other parameters. For $\mathrm{Hg}$, uncertainty in NOAEL is also important, but the study has also identified uncertainty in $\mathrm{Hg}$ content of prey items, FIR, and relative presence of $\mathrm{MeHg}$ as being important sources of uncertainty on which future research should be focussed.

\section{Overwintering birds}

In the context of this modelling study, it is important to realise that, for waders that overwinter in Poole Harbour or the Severn Estuary and migrate to breeding grounds elsewhere, exposure to metal contaminants at the time of breeding may be quite different to that experienced during the winter. It is uncertain what, if any, impacts previous overwinter exposure(s) to $\mathrm{Pb}$ or $\mathrm{Hg}$ may have on subsequent breeding success. Some of the contaminants accumulated over winter may be remobilised. For example, $\mathrm{Pb}$ sequestered in bone may be 
remobilised as bone (and calcium) turnover increases during egg production, or $\mathrm{MeHg}$ in fat may be remobilised as energy reserves are depleted during migration, immediately before breeding starts. There are no toxicological studies that we are aware of that specifically investigate the effects of prior exposures to $\mathrm{Pb}$ and $\mathrm{Hg}$ on subsequent reproduction; exposure typically occurs prior to and/or during the reproductive cycle. Pharmaco-kinetic modelling would therefore be needed to estimate the likely extent of remobilisation of previously accumulated contaminants and how this might supplement the internal dose derived from dietary intake on the breeding grounds

The other principal way in which metal intake on overwintering grounds could have ecologically significant effects is their potential contribution to direct over-winter mortality or decrease in likelihood of survival during spring migration. There are no suitable toxicity test endpoints to assess whether survival during migration could be affected. Thus, the only available data are for acute toxicity data $\left(\mathrm{LD}_{50} / \mathrm{LC} \mathrm{C}_{50} / \mathrm{NOAEL}\right.$ data), which are also sparse for inorganic $\mathrm{Pb}$ and $\mathrm{Hg}$ in birds. We did not attempt to use acute toxicity endpoints in most of the probabilistic models but had sufficient ecotoxicological data for methyl-mercury to carry out an assessment using a NOAEL for survival. This was derived by dividing the $\mathrm{LD}_{50}$ data by 100 . When this endpoint was used, the modelled median PPC/PNEC ratios were all extremely low, the $95^{\text {th }}$ percentile for the worst case scenario being 0.5 . Thus, from this limited assessment, there is no evidence that overwinter dietary intake of $\mathrm{Pb}$ or $\mathrm{Hg}$ poses an acute toxic threat to dunlin on the Severn Estuary or Poole Harbour. 
404 The Monte-Carlo based model presented here is able to assess the degree of risk posed to birds feeding on important estuarine habitats, and also shows the limitations of such risk assessments, particularly with regard to data quality and availability. This modelling study

407 indicates that internationally important feeding grounds for waders such as Poole Harbour 408 and the Severn Estuary may pose an ecologically-relevant toxic risk to wading birds. It was 409 found that there was a high probability that PPC/PNEC for $\mathrm{Pb}$ significantly exceeded 1 in 410 both areas for dunlin. There was also a high probability that PPC/PNEC for Hg significantly 411 exceeded 1 in the Severn Estuary and a significant (>5\%) probability that PPC/PNEC 412 exceeded 1 in Poole Harbour.

414 The model largely used data sets which would be typically available and necessary for assessing the impacts of contamination of large estuaries, although data describing feeding preferences and foraging patterns for waders are rarely site-specific. Whilst acknowledging

417 the inevitable limitations in using such data sets (which are made up of data from a number of 418 sources), their use gives a realistic estimate of uncertainty in environmental impact

419 assessments. Such an uncertainty based assessment gives important insights into the limitations of real environmental impact assessments.

422 Despite much previous work on its ecotoxicological impacts, a major source of uncertainty in 423 predicting PPC/PNEC values for $\mathrm{Pb}$ was the large uncertainty in NOAEL values. Generation 424 of further experimental toxicity data for metals in birds is likely to be extremely limited because of the ethical concerns associated with such work, and it is doubtful that there will be significant reduction in the future in the uncertainty associated with these measures. For $\mathrm{Hg}$, 
the amount of $\mathrm{Hg}$ present as MeHg, FIR and prey metal concentrations were also important sources of uncertainty and further studies to improve the precision of measurements of these parameters would reduce some of the uncertainty when estimating the risks of $\mathrm{Hg}$ to wading

430 birds.

Use of lethal toxicity data (LD50/100) was investigated as a method for assessing sub-lethal impacts from $\mathrm{Hg}$. It was found that this method led to a significant under-estimate of the potential impact of $\mathrm{Hg}$ contamination, as compared with direct estimation of NOAEL.

If significant toxic risk is still predicted following appropriate studies to reduce the uncertainty associated with contaminant levels in prey species, field studies to assess contaminant residues and relevant health indices in waterbirds should be undertaken. These should be focussed on high risk sites where inputs of relevant contaminants are ongoing. An approach which makes use of waterbird carcasses (found dead at relevant sites), similar to the UK's Predatory Bird Monitoring Scheme, should be considered, to provide further insight into the significance of the risk predictions made through the modelling work reported here. Application of non-invasive biomarkers to samples which could potentially be collected during routine ringing operations may provide useful supplementary information. 


\section{ACKNOWLEDGEMENTS}

453

454 The authors would like to thank the Steering Group for this project, namely Jennifer Best

455 (Natural England), Peter Jonas (Environment Agency) and Chris Nikitik (Environment

456 Agency Wales). Thanks are also due to the Environment Agency for provision of data on

457 contaminant residues in Nereis in the Severn Estuary and Poole Harbour. 


\section{REFERENCES}

Bryan GW, Langston WJ. Bioavailability, accumulation and effects of heavy metals in sediments with special reference to United Kingdom estuaries: a review. Environmental Pollution 1992; 76: 89-131.

Bull KR, Every WJ, Freestone P, Hall JR, Osborn D, Cooke AS, et al. Alkyl lead pollution and bird mortalities on the Mersey Estuary, UK, 1979-1981. Environmental Pollution Series A, Ecological and Biological 1983; 31: 239-259.

Bull KR, Roberts RD, Inskip MJ, Goodman GT. Mercury Concentrations in Soil, Grass, Earthworms and Small Mammals near an Industrial Emission Source. Environmental Pollution 1977; 12: 135-140.

Crane M, Ward RM, McInnes RJ. Potential risks to shorebirds from exposure to contaminants in the Severn estuary, UK: A screening level study. English Nature, 2005, pp. 65.

Duquesne S, Newton LC, Giusti L, Marriott SB, Stärk H-J, Bird DJ. Evidence for declining levels of heavy-metals in the Severn Estuary and Bristol Channel, U.K. and their spatial distribution in sediments. Environmental Pollution 2006; 143: 187-196.

Durell SEALVd, Stillman RA, Caldow RWG, McGrorty S, West AD, Humphreys J. Modelling the effect of environmental change on shorebirds: a case study on Poole Harbour, U.K. Biological Conservation 2006; 131: 459-473.

Ferns PN, Anderson JI. Lead in the diet and body tissues of dunlins Calidris alpina from the Bristol Channel, UK. Environmental Pollution 1997; 96: 35-42.

Goss-Custard JD, McGrorty S, Pearson B, Clarke RT, Rispin WE, Durell SEALVd, et al. Prediction of post-barrage densities of birds. Vol.4: Birds. Department of Energy., 1988.

ISI. ISI Web of Knowledge, 2005.

Langston WJ, Chesman BS, Burt GR, Hawkins SJ, Readman J, Worsfold P. Characterisation of the South West European Marine Sites: The Severn Estuary pSAC, SPA. . Occasional Publications of the MBA No. 13. 13. Marine Biological Association, Plymouth, 2003b.

Langston WJ, Chesman, B.S., Burt, G.R., Hawkins, S.J., Readman, J., Worsfold, P. Characterisation of the South West European Marine Sites: Poole Harbour SPA. Occasional Publications of the MBA No. 12. Marine Biological Association, Plymouth, 2003a.

Morgan JE, Morgan AJ. Differences in the Accumulated Metal Concentrations in 2 Epigeic Earthworm Species (Lumbricus-Rubellus and Dendrodrilus-Rubidus) Living in Contaminated Soils. Bulletin of Environmental Contamination and Toxicology 1991; 47: 296-301.

Muhaya BBM, Leermakers M, Baeyens W. Total mercury and methylmercury in sediments and in the polychaete Nereis diversicolor at Groot Buitenschoor (Scheldt estuary, Belgium). Water Air and Soil Pollution 1997; 94: 109-123.

Nagy KA. Food requirements of wild animals: Predictive equations for free-living mammals, reptiles and birds. Nutrition Abstracts and Reviews Series B: Livestock Feeds and Feeding 2001; 71: 21-31.

Pain DJ, Sanchez A, Meharg AA. The Donana ecological disaster: Contamination of a world heritage estuarine marsh ecosystem with acidified pyrite mine waste. Science of the Total Environment 1998; 222: 45-54.

Pickess BP, Underhill-Day JC. Important Birds of Poole Harbour. Wareham: Poole Harbour Study Group, 2002. 
Pirrie D, Power MR, Rollinson G, Camm GS, Hughes SH, Butcher AR, et al. The spatial distribution and source of arsenic, copper, tin and zinc within the surface sediments of the Fal Estuary, Cornwall, UK. Sedimentology, 50(3): 579-595. Sedimentology 2003; 50: 579-595.

Pollitt MS, Hall C, Holloway SJ, Hearn RD, Marshall PE, Musgrove AJ, et al. The Wetland Bird Survey 2000-01: Wildfowl and Wader Counts. Slimbridge: BTO/WWT/RSPB/JNCC, 2003.

Sample BE, Opresko DM, Suter II GW. Toxicological Benchmarks for Wildlife: 1996 Revision. Oak Ridge National Laboratory, Oak Ridge, TN., 1997, pp. 217.

Sheppard SC, Evenden WG, Schwarz WJ. Ingested soil: bioavailability of sorbed lead, cadmium, cesium, iodine and mercury. Journal of Environmental Quality 1995; 24: 498-505.

Spurgeon DJ. The ecological relevance of the OECD earthworm toxicity test, and its use in establishing soil quality criteria. PhD Thesis. University of Reading, Reading, UK, 1994, pp. 273.

Stillman RA, West AD, Durell SEALVd, Caldow RWG, McGrorty S, Yates M, et al. Estuary special protection areas - establishing baseline targets for shorebirds. Final report. English Nature, 2005, pp. 157.

U.S. Environmental Protection Agency. Data collection for the hazardous waste identification rule. Section 14.0 ecological benchmarks. Office of Solid Waste, Washington, DC, 1999 , pp. 105.

U.S. Environmental Protection Agency. ECOTOXicology Database System. Office of Research and Development,, U.S. Environmental Protection Agency, 2002.

U.S. Environmental Protection Agency. Ecological soil screening levels for lead. Office of Solid Waste and Emergency Response, Washington, DC, 2005, pp. 242.

USACHPPM. Technical Guide No. 254: Standard practice for wildlife toxicity values. U.S. Centre for health promotion and preventative medicine, 2000, pp. 45.

USEPA. Wildlife exposure factors handbook. Vol. 1. EPA/600/R-93/187. USEPA, Washington, 1993, pp. 572p.

Verdonck FA, Van Sprang PA, Vanrolleghem PA. Uncertainty and precaution in European environmental risk assessment of chemicals. Water Science \& Technology 2005; 52: 227-234.

World Health Organisation. Environmental Health Criteria 85: Lead- Environmental Aspects. Geneva: World Health Organisation, 1989a.

World Health Organisation. Environmental Health Criteria 86: Mercury - Environmental Aspects. Geneva: World Health Organisation, 1989b.

World Health Organisation. Environmental Health Criteria 101: Methylmercury. Geneva: World Health Organisation, 1990.

World Health Organisation. Environmental Health Criteria 118: Inorganic Mercury. Geneva: World Health Organisation, 1991.

Worrall DH. Diet of the Dunlin Calidris alpina in the Severn Estuary. Bird Study 1984; 31: 203-212. 


\section{Figure Captions}

Figure 1. Map of Severn and Poole Harbour estuaries.

Figure 2. Predicted PPC/PNEC of Pb in dunlin, Poole Harbour: Average Scenario. The histogram shows the frequency of given PPC/PNEC output values out of 10,000 model runs. Percentage cumulative frequency is shown by the grey line using the right-hand vertical axis. The uncertainty is very high (note the logarithmic scale on the $\mathrm{X}$-axis) due primarily to uncertainty in NOAEL (see Sensitivity Analysis section).

Figure 3. $\mathrm{Hg}$ in Dunlin, Severn Estuary, assuming mean fraction of $\mathrm{MeHg}=18 \%$. The histograms show the frequency of given PPC/PNEC output values out of 10,000 model runs. Percentage cumulative frequency is shown by the grey line using the right-hand vertical axis. Worst case scenario for PNEC based on (a) LD50/100 or (b) NOAEL based on reproductive endpoints. PPC/PNEC is predicted to be significantly greater than 1 based on NOAEL, but less than 1 based on LD50/100.

Figure 4. Median predicted values of PPC/PNEC for lead in dunlin in Poole Harbour and the Severn Estuary. Error bars show the range of 5-95 percentile predicted values.

Figure 5. Median, predicted values of PPC/PNEC for $\mathrm{Hg}$ in dunlin where PNEC is based either on an NOAEL or on LD50/100 in (a) Poole Harbour and (b) the Severn Estuary. Error bars show the range of 5-95 percentile predicted values.

Figure 6 Sensitivity analysis: $\mathrm{Pb}$ in dunlin, Poole Harbour (Ave. Scenario). The variation of predicted PPC/PNEC is shown given variation in different individual input parameters, and for variation in all parameters. Uncertainty in NOAEL for $\mathrm{Pb}$ dominates uncertainty in PPC/PNEC.

Figure 7 Sensitivity analysis: $\mathrm{Hg}$ in dunlin, Severn Estuary (Ave. Scenario). Uncertainty in $\% \mathrm{MeHg}$ in diet, $\mathrm{Hg}$ content of molluscs, FIR and NOAEL all contribute significantly to uncertainty in PPC/PNEC 


\section{TABLES}

Table 1. Percentage of different food types taken by adult (Average Scenario) and juvenile (Worst Case Scenario) dunlin in Poole Harbour and the Severn Estuary.

\begin{tabular}{|l|l|}
\hline Poole Harbour & Percentage food type \\
\hline Marine worms & $78 \%$ S.D. 5\% \\
\hline Molluscs & $100 \%$ minus \% of marine worms \\
\hline Crustaceans & \\
\hline Earthworms & 0 \\
\cline { 1 - 2 } Severn Estuary & \\
\hline Marine worms & $58 \%$ S.D. 10\% \\
\hline Molluscs & $100 \%$ minus $\Sigma$ other \\
\hline Crustaceans & 0 \\
\hline Earthworms & $0-10 \%$ \\
\hline
\end{tabular}


Table 2. Assumed distributions (mean \pm S.E. or range) of lead and mercury in prey items for the Average Scenario based on measured data for ragworms and from a literature review for other species (see Tables S3-S6).

\begin{tabular}{|c|c|c|c|c|}
\hline Prey type & $\begin{array}{c}\text { Pb - Poole H. } \\
\text { mg/kg DW }\end{array}$ & $\begin{array}{l}\text { Assumed } \\
\text { distribution }\end{array}$ & $\begin{array}{c}\text { Pb - Severn Est. } \\
\text { mg/kg DW }\end{array}$ & $\begin{array}{c}\text { Assumed } \\
\text { distribution }\end{array}$ \\
\hline Nereis & $0.71 \pm 0.11$ & Normal & $1.51 \pm 0.32$ & Normal \\
\hline $\begin{array}{l}\text { Molluscs \& } \\
\text { crustaceans }\end{array}$ & $0.24-7.1$ & Uniform & $0.50-15.1$ & Uniform \\
\hline Earthworms & $4-27$ & Uniform & $4-27$ & Uniform \\
\hline Prey type & $\begin{array}{c}\mathrm{Hg} \text { - Poole H. } \\
\text { mg/kg DW }\end{array}$ & $\begin{array}{c}\text { Assumed } \\
\text { distribution }\end{array}$ & $\begin{array}{c}\text { Hg - Severn Est. } \\
\text { mg/kg DW }\end{array}$ & $\begin{array}{c}\text { Assumed } \\
\text { distribution }\end{array}$ \\
\hline Nereis & $0.076 \pm 0.0068$ & Normal & $0.48 \pm 0.1$ & Normal \\
\hline $\begin{array}{l}\text { Molluscs and } \\
\text { crustaceans }\end{array}$ & $0.025-0.76$ & Uniform & $0.16-1.44$ & Uniform \\
\hline Earthworms & Insufficient data & & Insufficient data & \\
\hline
\end{tabular}


Table 3. Ranges and assumed probability distributions of NOAEL and LD50/100 values for $\mathrm{Pb}$ and $\mathrm{Hg}$ (see Table $\mathrm{S} 7$ for details of the studies on which these are based).

\begin{tabular}{llll}
\hline Metal & Endpoint & $\begin{array}{l}\text { Range } \\
\text { mgMetal/kgBW/d }\end{array}$ & $\begin{array}{l}\text { Assumed probability } \\
\text { distribution }\end{array}$ \\
\hline $\mathrm{Pb}$ & NOAEL & $0.011-1.6$ & $\begin{array}{l}\text { Uniform distribution of log- } \\
\text { transformed values }\end{array}$ \\
\hline $\mathrm{MeHg}$ & NOAEL & $0.0038-0.0108$ & Uniform \\
\hline $\mathrm{MeHg}$ & LD50/100 & $0.195-0.378$ & Uniform \\
\hline $\mathrm{IOM}$ & NOAEL & $0.45-5.5$ & Uniform \\
\hline $\begin{array}{l}\text { a. } \\
\text { A uniform distribution assumes that the endpoint can take any value between the upper and lower } \\
\text { bounds with equal probability. }\end{array}$
\end{tabular}


Table 4. Median, 5 and 95 percentile PEC/PNEC values for dunlin exposed to $\mathrm{Pb}$ and $\mathrm{Hg}$ in Poole Harbour and the Severn Estuary.

\begin{tabular}{|c|c|c|c|c|c|}
\hline Metal & Scenario & $\begin{array}{l}\text { Basis for } \\
\text { PNEC }\end{array}$ & $\begin{array}{l}\text { PEC/PNEC } \\
5 \%\end{array}$ & $\begin{array}{l}\text { PEC/PNEC } \\
50 \%\end{array}$ & $\begin{array}{l}\text { PEC/PNEC } \\
95 \%\end{array}$ \\
\hline \multicolumn{6}{|c|}{ Poole Harbour } \\
\hline $\mathrm{Pb}$ & Average & NOAEL & 0.18 & 1.97 & 21.8 \\
\hline $\mathrm{Hg}$ & Average & NOAEL & 0.23 & 0.79 & 2.41 \\
\hline $\mathrm{Hg}$ & Average & LD50/100 & 0.0061 & 0.02 & 0.055 \\
\hline $\mathrm{Pb}$ & Worst Case & NOAEL & 0.48 & 5.62 & 58.0 \\
\hline $\mathrm{Hg}$ & Worst Case & NOAEL & 0.45 & 1.39 & 4.34 \\
\hline $\mathrm{Hg}$ & Worst Case & LD50/100 & 0.012 & 0.035 & 0.10 \\
\hline \multicolumn{6}{|c|}{ Severn Estuary } \\
\hline $\mathrm{Pb}$ & Average & NOAEL & 0.58 & 6.45 & 74.6 \\
\hline $\mathrm{Hg}$ & Average & NOAEL & 1.01 & 3.37 & 10.7 \\
\hline $\mathrm{Hg}$ & Average & LD50/100 & 0.035 & 0.084 & 0.19 \\
\hline $\mathrm{Pb}$ & Worst Case & NOAEL & 1.11 & 11.7 & 121 \\
\hline $\mathrm{Hg}$ & Worst Case & NOAEL & 2.31 & 6.94 & 21.9 \\
\hline $\mathrm{Hg}$ & Worst Case & LD50/100 & 0.060 & 0.18 & 0.51 \\
\hline
\end{tabular}


Figure 1 Map of Severn and Poole Harbour estuaries.

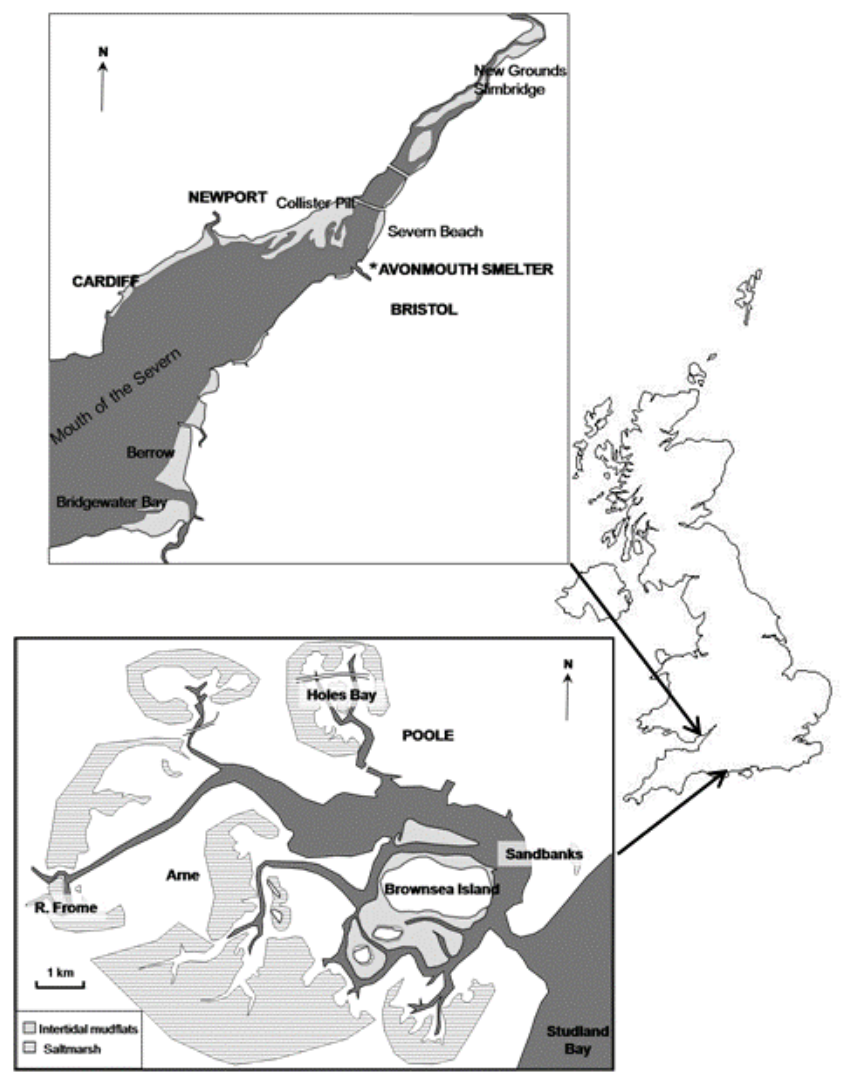




\section{FIGURES 2-7}

$\mathrm{Pb}$ in Dunlin: Average Scenario

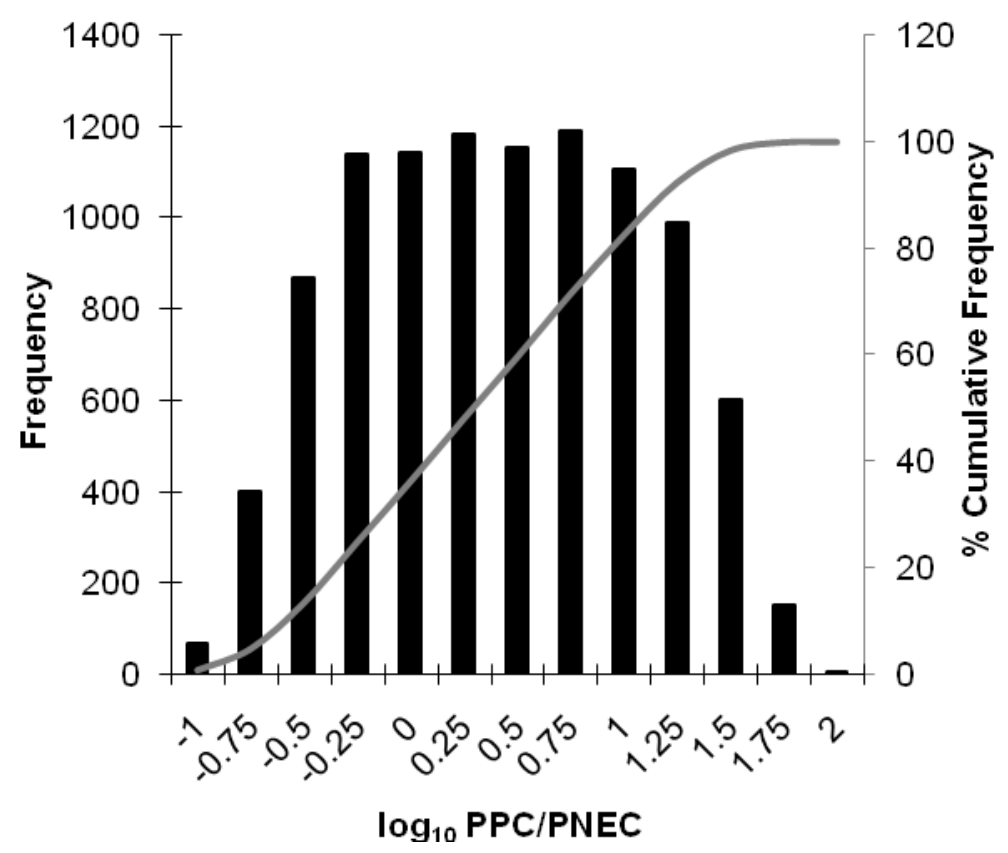

Figure 2. Predicted PPC/PNEC of Pb in dunlin, Poole Harbour: Average Scenario. The histogram shows the frequency of given PPC/PNEC output values out of 10,000 model runs. Percentage cumulative frequency is shown by the grey line using the right-hand vertical axis. The uncertainty is very high (note the logarithmic scale on the $\mathrm{X}$-axis) due primarily to uncertainty in NOAEL (see Sensitivity Analysis section). 
(a) Dunlin $18 \%$ MeHg Worst Case

Scenario using LD50/100

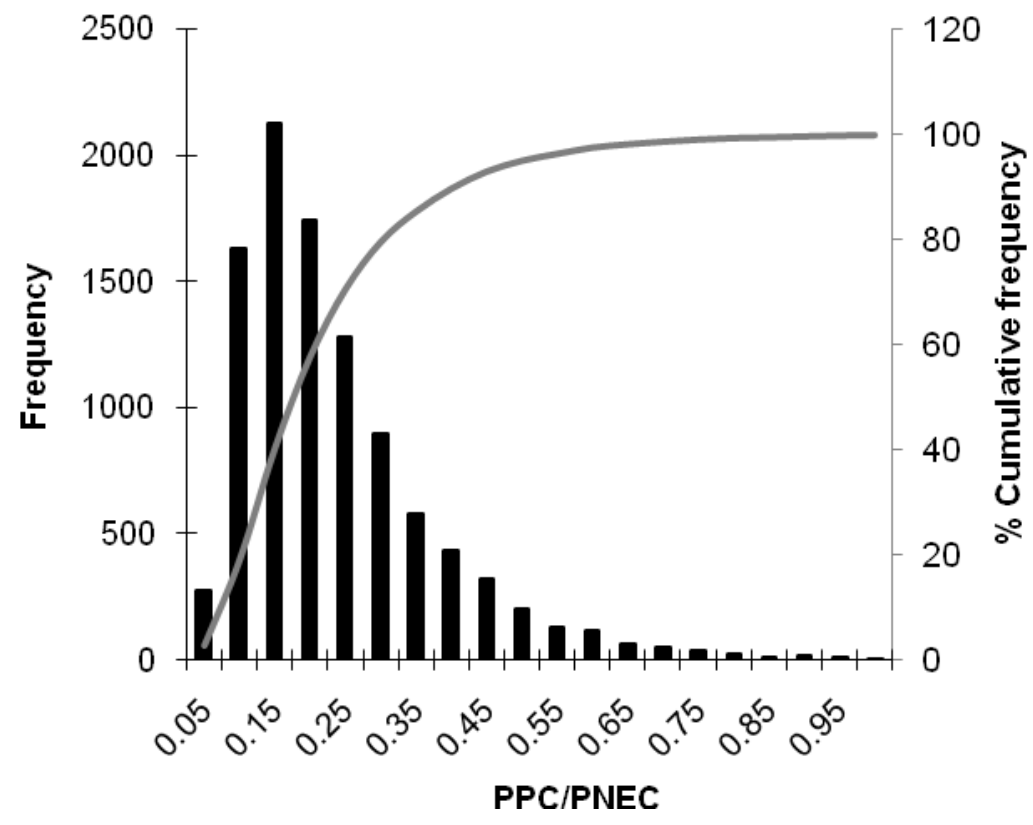

(b) Dunlin $18 \%$ MeHg Worst Case Scenario using NOAEL

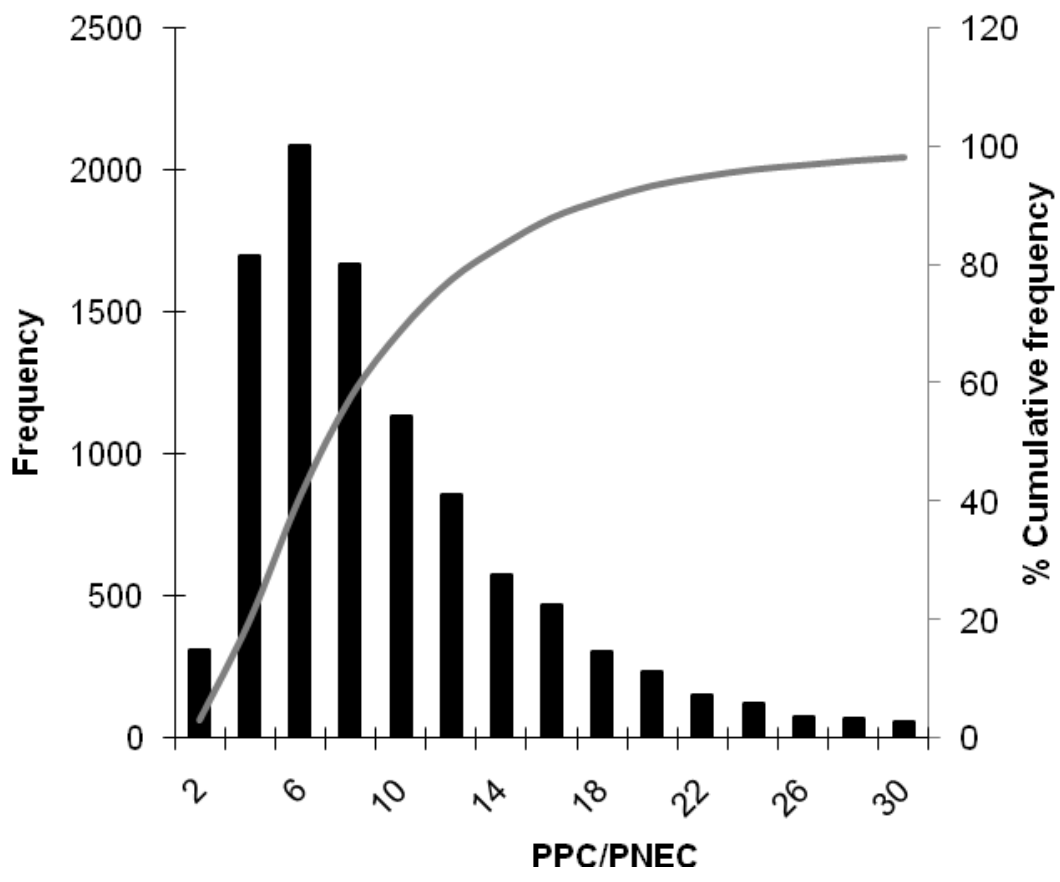

Figure 3. $\mathrm{Hg}$ in Dunlin, Severn Estuary, assuming mean fraction of $\mathrm{MeHg}=18 \%$. The histograms show the frequency of given PPC/PNEC output values out of 10,000 model runs. Percentage cumulative frequency is shown by the grey line using the right-hand vertical axis. Worst case scenario for PNEC based on (a) LD50/100 or (b) NOAEL based on reproductive endpoints. PPC/PNEC is predicted to be significantly greater than 1 based on NOAEL, but less than 1 based on LD50/100. 


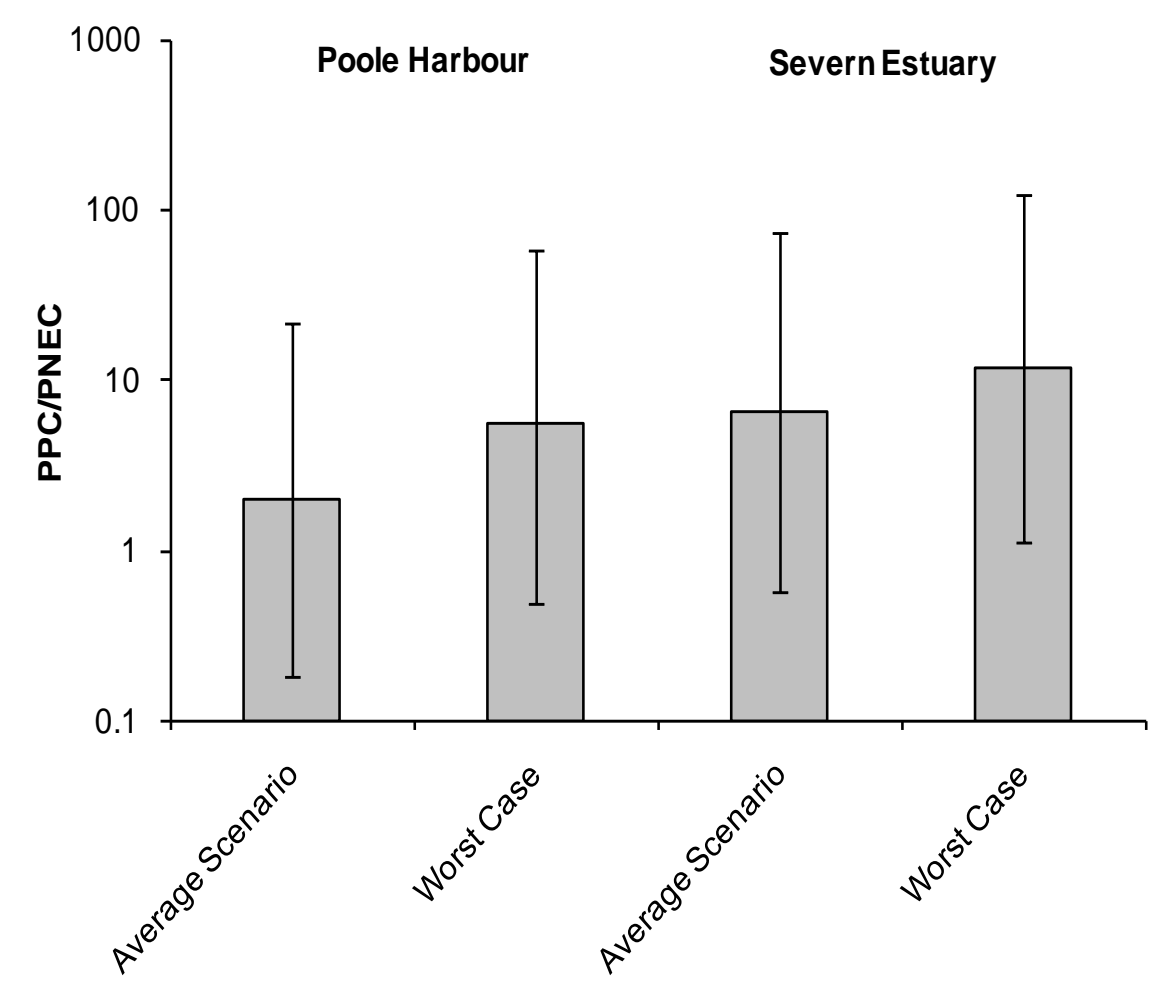

Figure 4. Median predicted values of PPC/PNEC for lead in dunlin in Poole Harbour and the Severn Estuary. Error bars show the range of 5-95 percentile predicted values. 
(a) $\mathrm{Hg}$ in Poole Harbour

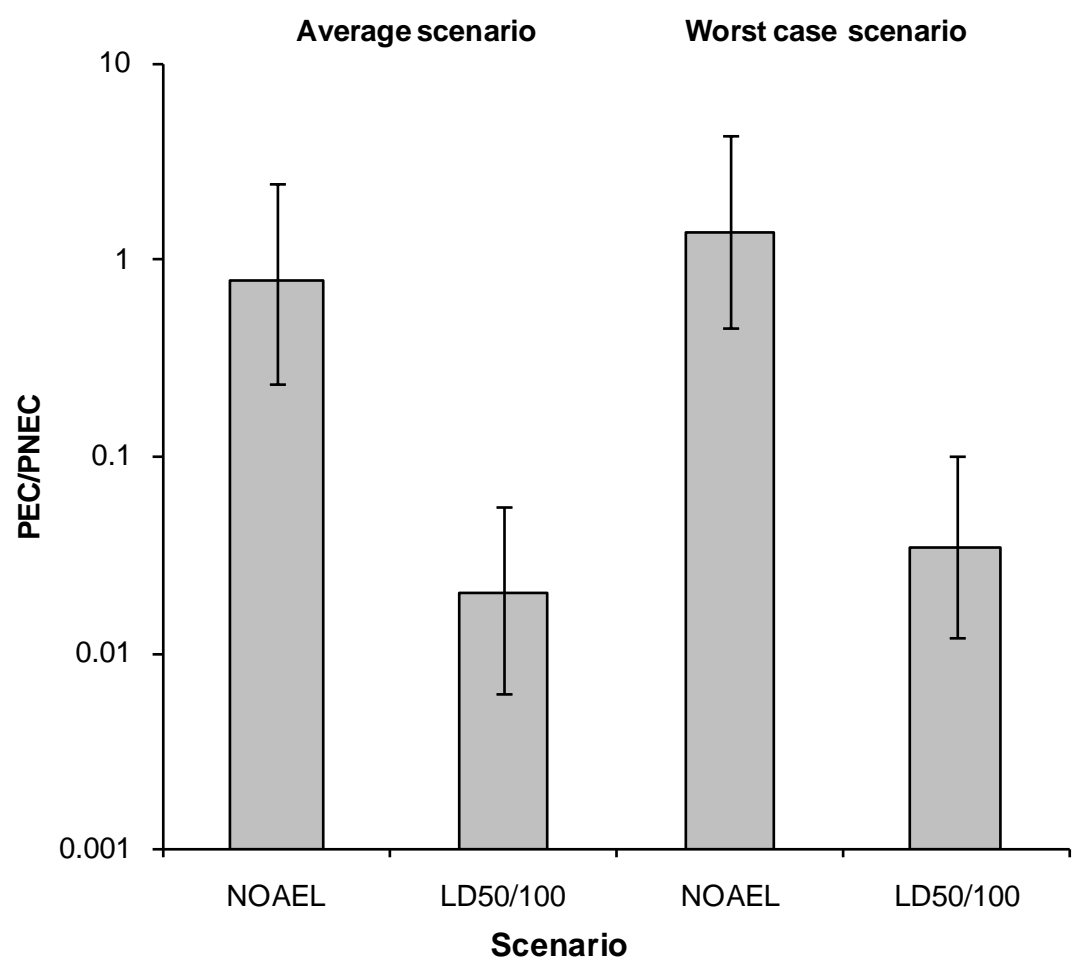

(b) $\mathrm{Hg}$ in the Severn Estuary

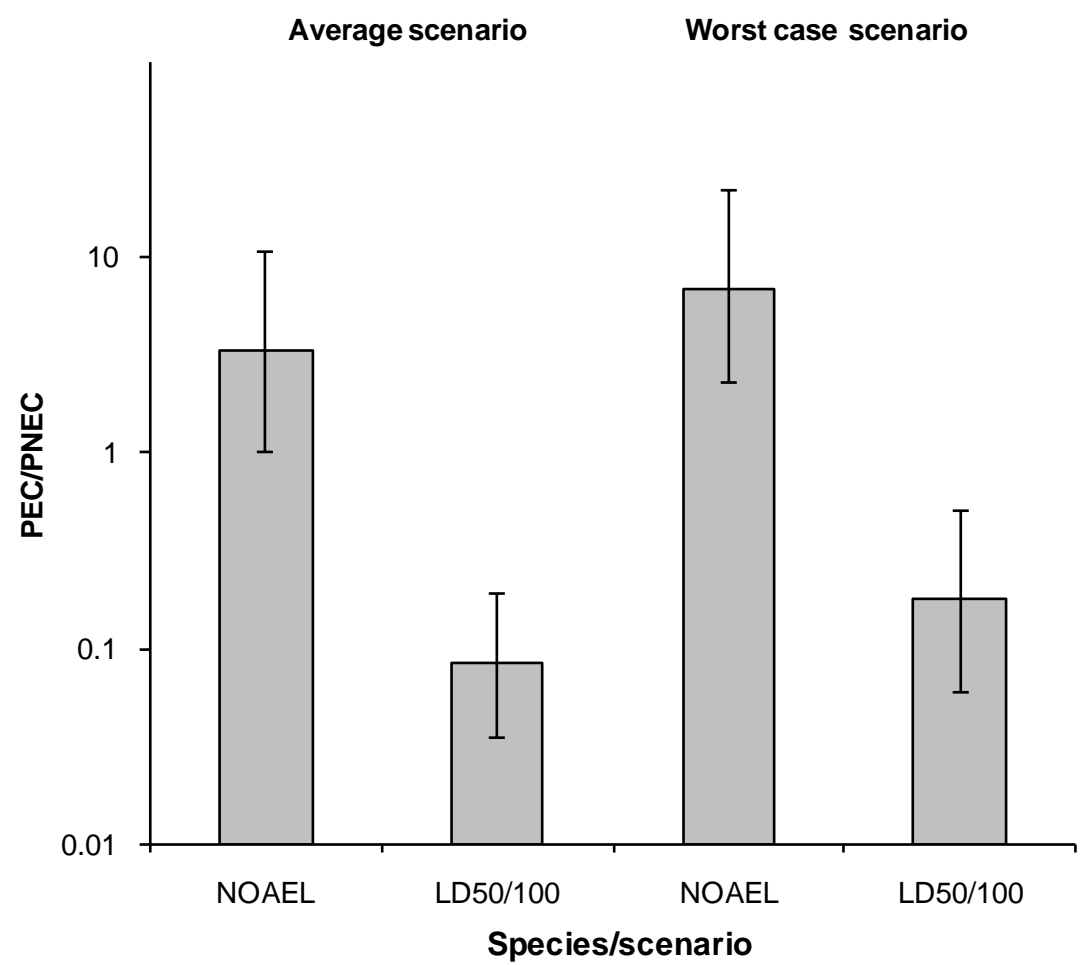

Figure 5. Median, predicted values of PPC/PNEC for $\mathrm{Hg}$ in Dunlin where PNEC is based either on an NOAEL or on LD50/100 in (a) Poole Harbour and (b) the Severn Estuary. Error bars show the range of 5-95 percentile predicted values. 
$\%$ Nereis in diet varied

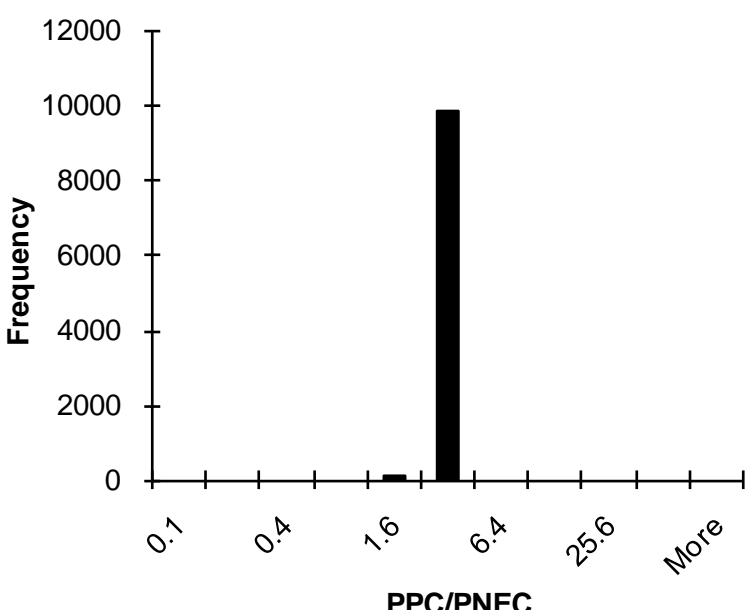

Food Intake Rate varied

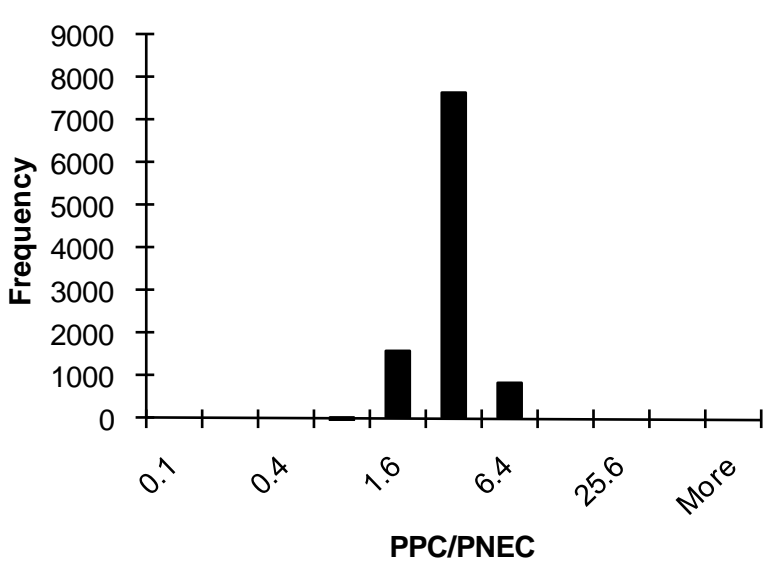

$\mathrm{Pb}$ in Nereis varied

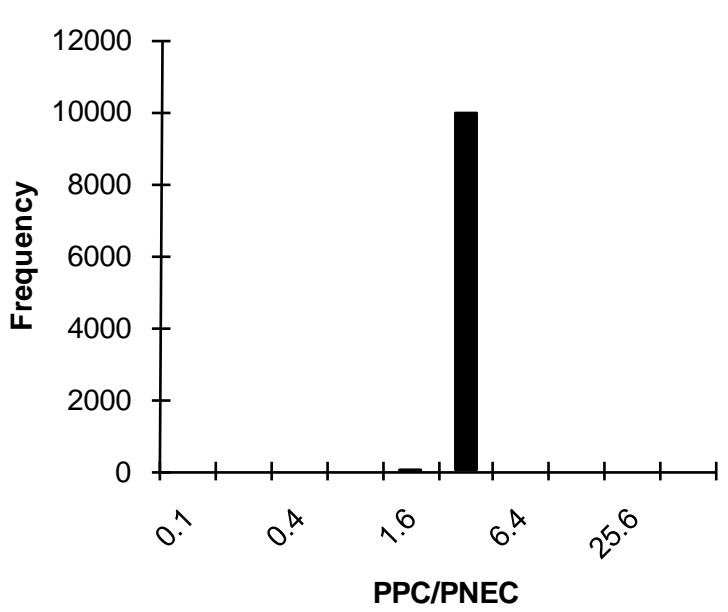

NOAEL varied

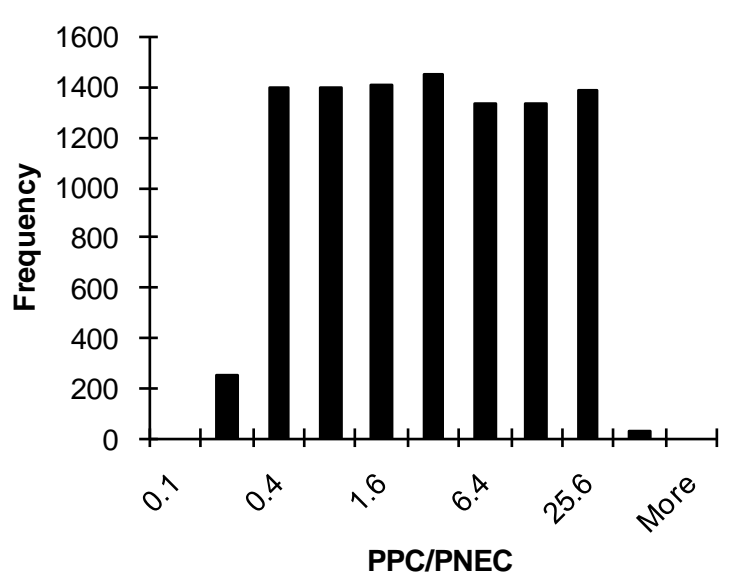

$\mathrm{Pb}$ in molluscs \& crustaceans varied

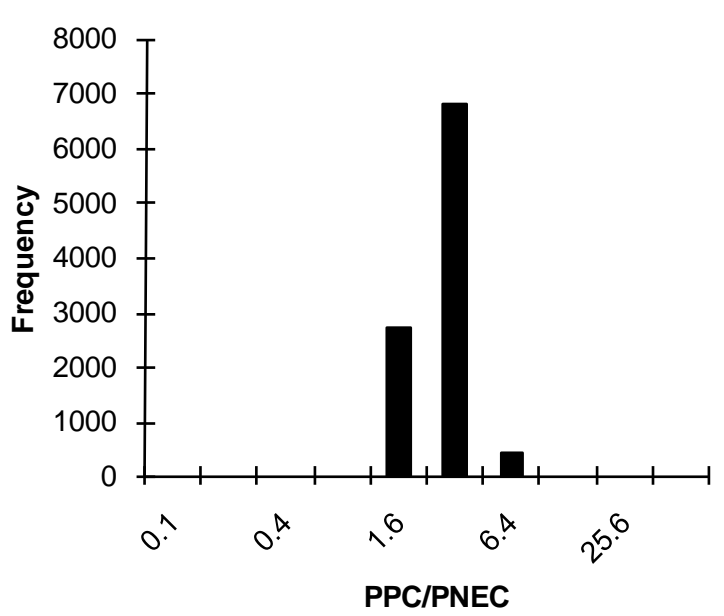

All parameters varied

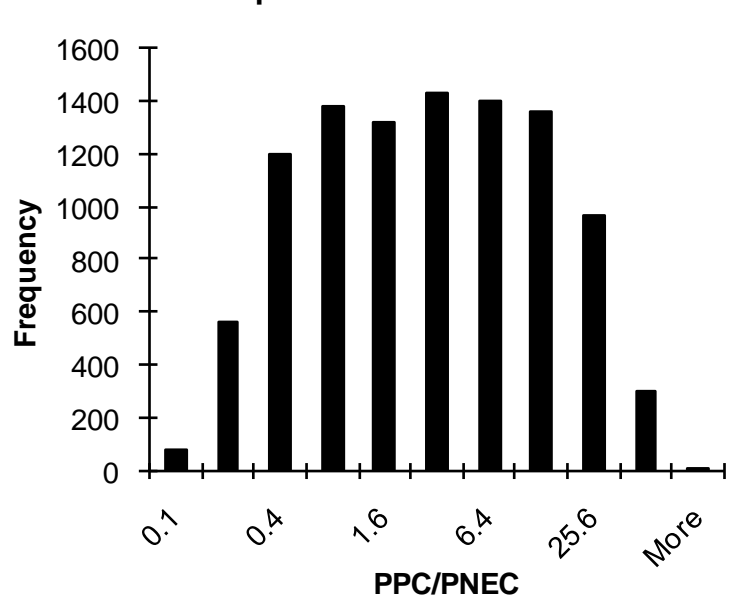

Figure 6 Sensitivity analysis: $\mathrm{Pb}$ in Dunlin, Poole Harbour (Ave. Scenario). The histograms show the frequency of given PPC/PNEC output values out of 10,000 model runs. The variation of predicted PPC/PNEC is shown given variation in different individual input parameters, and for variation in all parameters. Uncertainty in NOAEL for $\mathrm{Pb}$ dominates uncertainty in PPC/PNEC. 

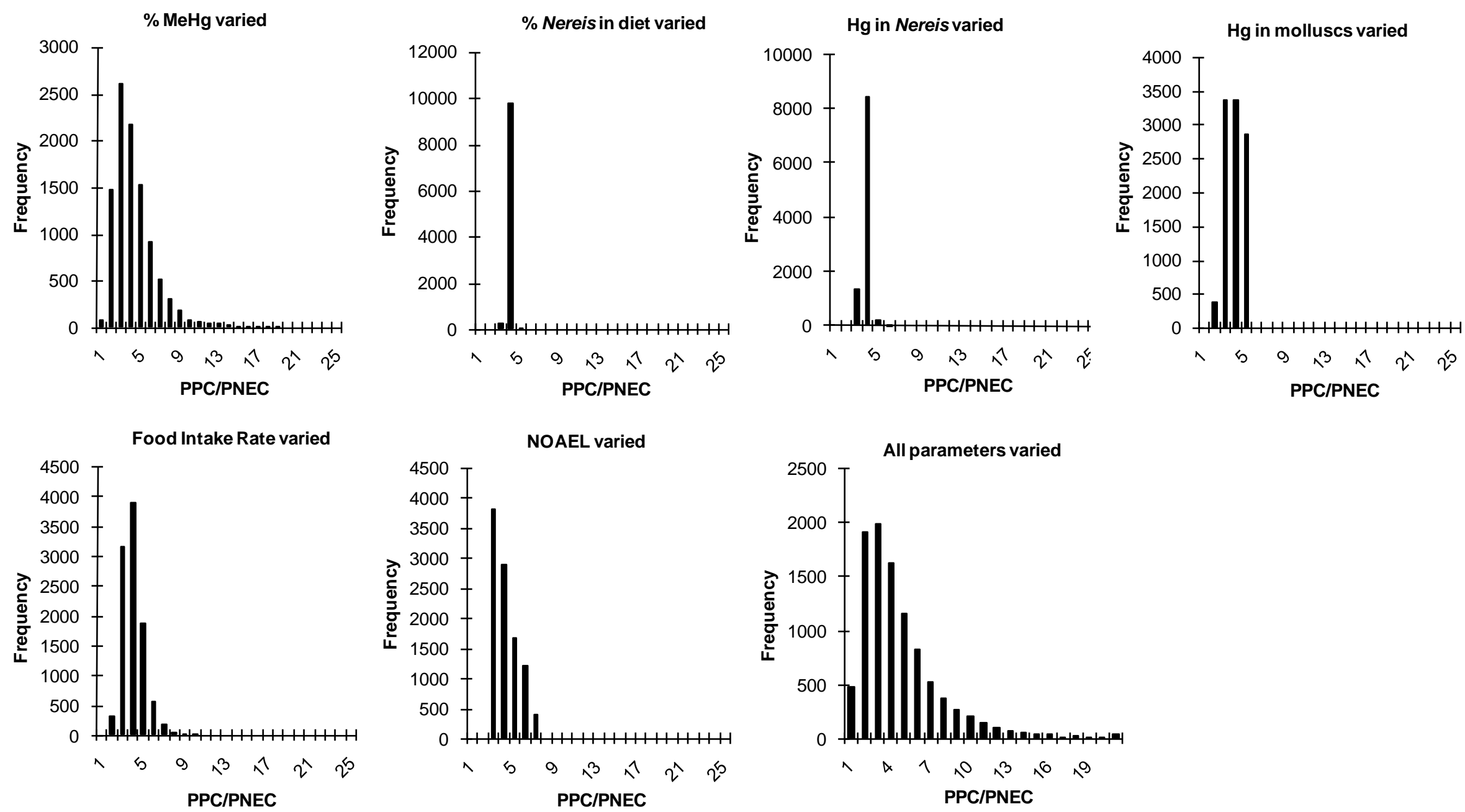

Figure 7 Sensitivity analysis: Hg in Dunlin, Severn Estuary (Ave. Scenario). The histograms show the frequency of given PPC/PNEC output values out of 10,000 model runs. Uncertainty in $\% \mathrm{MeHg}$ in diet, $\mathrm{Hg}$ content of molluscs, FIR and NOAEL all contribute significantly to uncertainty in PPC/PNEC 


\section{SUPPLEMENTARY MATERIAL}

Table S1. Maximum PPC/PNEC estimated from measurements of contaminants in Nereis diversicolor (Environment Agency, unpubl. res.) at 12 sites in Poole Harbour. Contaminants with PPC/PNEC > 1 are highlighted in bold font.

\begin{tabular}{|c|c|c|c|c|}
\hline Contaminant & $\begin{array}{l}\text { Measured } \\
\text { concentrati } \\
\text { on (Range) } \\
\text { mg/kg f.w. }\end{array}$ & $\begin{array}{c}\text { NOAEL } \\
\text { mg/kgBW/ } \\
\text { d }\end{array}$ & $\begin{array}{c}\text { Max. } \\
\text { PPC/PNEC }\end{array}$ & Notes \\
\hline Copper & $1.8-6.8$ & $47.0[1]$ & 0.073 & \\
\hline Silver & $0.23-0.36$ & $>2.3[2]$ & $<0.12$ & Used LC50×FIR/1000 \\
\hline Zinc & $19-44$ & $11 \quad[3]$ & 3.15 & \\
\hline Cadmium & $0.011-0.36$ & $1.45[4]$ & 0.08 & \\
\hline Mercury & $\begin{array}{ll}0.0086 & - \\
0.026 & -\end{array}$ & 0.0064 [5] & 3.1 & $\begin{array}{l}\text { Assume NOAEL }=\text { LOAEL/10 } \\
\text { A NOAEL for mercury as organo-metal } \\
\text { (methylmercury) was chosen. }{ }^{\text {a }}\end{array}$ \\
\hline Lead & $0.11-0.36$ & $0.021[6]$ & 14 & \\
\hline Vanadium & $<0.23-0.48$ & 1.5 & 0.25 & \\
\hline Arsenic & $1.5-6.0$ & $10.0[8]$ & 0.47 & \\
\hline Chromium & $<0.23-0.48$ & $1.0 \quad[3]$ & 0.37 & \\
\hline Manganese & $1.0-3.6$ & 977 [9] & 0.0029 & \\
\hline Iron & $67-285$ & $1.03[2]$ & 216 & $\begin{array}{l}\text { Used LC } 50 \times \text { FIR/ } 1000 \text {. } \\
\text { But NOAEL lower than daily iron } \\
\text { requirement. }\end{array}$ \\
\hline Nickel & $0.41-1.5$ & $\begin{array}{ll}77.4 \quad[10] \\
\end{array}$ & 0.015 & \\
\hline PAHs & $\begin{array}{l}<0.0005- \\
1.1\end{array}$ & $\begin{array}{l}1.43 \quad[11] \\
\text { Benzo(a)pyrene }\end{array}$ & All $<1$ & $\begin{array}{l}\text { Checked each individual PAH against } \\
\text { NOAEC for Benzo(a)pyrene, the most } \\
\text { toxic PAH. }\end{array}$ \\
\hline Tributyl tin & n.d. & $\begin{array}{ll}6.8 & {[12]}\end{array}$ & - & $\begin{array}{l}\text { All measured values were below limit of } \\
\text { detection. }\end{array}$ \\
\hline
\end{tabular}

a. There is a large disparity between NOAELs for mercuric chloride and methylmercury $(0.45 \mathrm{cf} .0 .0064 \mathrm{mg} / \mathrm{kg}$ bw/d respectively). Using the NOAEL for methyl mercury over estimates the risk. [1] (Mehring et al., 1960) ; [2] (U.S. Environmental Protection Agency, 2002); [3] (Sample et al., 1997); [4] (White and Finley, 1978); [5] (Heinz, 1979); [6] (Edens and Garlich, 1983); [7] (Romoser et al., 1961) [8] (Stanley et al., 1994); [9] (Laskey and Edens, 1985); [10] (Cain and Pafford, 1981); [11] (Hough et al., 1993); [12] (Schlatterer et al., 1993); 
Table S2. Maximum PPC/PNEC estimated from measurements of contaminants in Nereis diversicolor at 13 sites in the Severn Estuary. The range of organic contaminants that were analysed for was greater than in the Nereis collected from Poole Harbour (Table S1).

\begin{tabular}{|c|c|c|c|c|}
\hline Contaminant & $\begin{array}{c}\text { Measured } \\
\text { conc. (Range) } \\
\text { mg/kg f.w. }\end{array}$ & $\begin{array}{l}\text { NOAEL } \\
\mathrm{mg} / \mathrm{kgBW} / \mathrm{d}\end{array}$ & $\begin{array}{c}\text { Max. } \\
\text { PPC/PNEC }\end{array}$ & Notes \\
\hline Copper & $7.2-20$ & $47.0[1]$ & 0.33 & \\
\hline Silver & $0.25-1.6$ & $>2.3 \quad[2]$ & $<0.53$ & Used LC50*FIR/1000 for NOAEL \\
\hline Zinc & $20-55$ & $11 \quad[3]$ & 3.9 & \\
\hline Cadmium & $0.024-0.25$ & $1.45[4]$ & 0.13 & \\
\hline Mercury & $0.039-0.20$ & 0.0064 [5] & 22.5 & $\begin{array}{l}\text { Assume NOAEL = LOAEL/10. } \\
\text { Used a NOAEL for mercury as organo- } \\
\text { metal (methylmercury). There is a large } \\
\text { disparity between NOAELs for mercuric } \\
\text { chloride and methylmercury ( } 0.45 \mathrm{cf} \text {. } \\
0.0064 \mathrm{mg} / \mathrm{kg} \text { bw/d respectively). }\end{array}$ \\
\hline Lead & $0.18-0.53$ & $0.021 \quad[6]$ & 34.2 & \\
\hline Arsenic & $1.4-4.9$ & $10.0[7]$ & 0.38 & \\
\hline Chromium & $0.20-1.3$ & $1.0 \quad[3]$ & 1.0 & \\
\hline Nickel & $0.32-1.3$ & $77.4[8]$ & 0.013 & \\
\hline Selenium & $1.2-3.1$ & $0.5 \quad[9]$ & 4.9 & Assume NOAEL $=$ LOAEL $/ 10$ \\
\hline PAHs & $<0.0005-0.8$ & $\begin{array}{l}1.43 \quad[10] \\
\text { (Benzo(a)pyre } \\
\text { ne) }\end{array}$ & All $<1$ & $\begin{array}{l}\text { Checked each individual PAH against } \\
\text { NOAEL for Benzo(a)pyrene, the most } \\
\text { toxic PAH. }\end{array}$ \\
\hline PCBs & $\begin{array}{l}\quad 0.0001- \\
0.0086\end{array}$ & $\begin{array}{l}0.18 \quad[11] \\
\text { (Arochlor } \\
1254)\end{array}$ & Sum $<1$ & $\begin{array}{l}\text { Checked sum of PCBs vs NOAEL for } \\
\text { Arochlor } 1254 \text {. }\end{array}$ \\
\hline Tributyl tin & n.d. ${ }^{b}$ & $6.8 \quad[12]$ & - & All measurements below L.O.D. ${ }^{b}$ \\
\hline $\begin{array}{l}\text { a,b,d,g- } \\
\text { hexachlorocycl } \\
\text { ohexane }\end{array}$ & n.d. & & & All measurements were below L.O.D. \\
\hline $\begin{array}{l}\text { Aldrin, } \\
\text { Dieldrin, } \\
\text { Endrin, Isodrin }\end{array}$ & n.d. & & & All measurements were below L.O.D. \\
\hline $\begin{array}{l}\text { op-DDT, } \\
\text { pp-DDT }\end{array}$ & n.d. & & & All measurements were below L.O.D. \\
\hline pp-DDE & $\begin{array}{l}<0.001- \\
0.0012\end{array}$ & & & $\begin{array}{l}\mathrm{LC} 50=825 \mathrm{mg} / \mathrm{kg} \text {. Max } 1.19 \mu \mathrm{g} / \mathrm{kg} \\
\text { in prey. Only } 2 \text { out of } 13 \text { samples } \\
\text { above L.O.D }\end{array}$ \\
\hline pp-TDE & $\begin{array}{l}<0.001- \\
0.0032\end{array}$ & & & $\begin{array}{l}1 \text { out of } 13 \text { samples above L.O.D. } \\
\text { Measured value } 3.2 \mu \mathrm{g} \mathrm{kg}^{-1} \text { f.w. LD50 } \\
=386 \mathrm{mg} \mathrm{kg}^{-1} \mathrm{BW} \text { acute dose. }\end{array}$ \\
\hline $\begin{array}{l}\text { Hexachloro- } \\
\text { butadiene, } \\
\text { Hexachloro- } \\
\text { benzene }\end{array}$ & n.d. & & & All measurements were below L.O.D. \\
\hline
\end{tabular}

a. n.d. - not detected; b. L.O.D - limit of detection in chemical analysis

[1] (Mehring et al., 1960) ; [2] (U.S. Environmental Protection Agency, 2002); [3] (Sample et al., 1997); [4] (White and Finley, 1978); [5] (Heinz, 1979); [6] (Edens and Garlich, 1983); [7] (Stanley et al., 1994); [8] (Cain and Pafford, 1981); [9] (Heinz et al., 1987); [10] (Hough et al., 1993); [11] (Dahlgren et al., 1972); [12] (Schlatterer et al., 1993); 
Table S3. Pb in various biota in comparison with Nereis, Poole Harbour

\begin{tabular}{|c|c|c|c|}
\hline Pb mg kg ${ }^{-1} \mathrm{DW}$ & Holes Bay & $\begin{array}{l}\text { Brownsea/main } \\
\text { harbour }\end{array}$ & Notes \\
\hline \multirow[t]{2}{*}{$\begin{array}{l}\text { Nereis (Hediste) } \\
\text { diversicolor } \\
\text { Ragworm }\end{array}$} & \multicolumn{2}{|l|}{$\begin{array}{l}<0.5-1.6 \\
\text { Mean: } 0.71 \\
\text { S.E.: } 0.11\end{array}$} & $\begin{array}{l}\text { This study, range for } \\
\text { Poole Harbour }\end{array}$ \\
\hline & 3.6 & & $\begin{array}{l}\text { Langston et al. unpubl. } \\
\text { Mean over } 25 \text { yr period. }\end{array}$ \\
\hline $\begin{array}{l}\text { Scrobicularia plana } \\
\text { Peppery furrow shell }\end{array}$ & 18 & 5.8 & $\begin{array}{l}\text { Langston et al. unpubl. } \\
\text { Mean over } 25 \text { yr period. } \\
\text { This study, Parkstone } \\
\text { Bay }\end{array}$ \\
\hline $\begin{array}{l}\text { Cerastoderma edule } \\
\text { Common cockle }\end{array}$ & 14 & 5 & $\begin{array}{l}\text { (Boyden, 1975) samples } \\
\text { from 1973-4 }\end{array}$ \\
\hline $\begin{array}{l}\text { Mytilus edulis } \\
\text { Common mussel }\end{array}$ & 19 & $\begin{array}{l}7 \\
10.5^{\mathrm{a}}\end{array}$ & $\begin{array}{l}\text { (Boyden, 1975) samples } \\
\text { from 1973-4 } \\
\text { (MAFF, 1998) Main } \\
\text { harbour, site not } \\
\text { specified. }\end{array}$ \\
\hline $\begin{array}{l}\text { Ostrea edulis } \\
\text { Native oyster }\end{array}$ & 1.2 & 0.35 & $\begin{array}{l}\text { (Langston, 2003a). Data } \\
\text { from } 1983 .\end{array}$ \\
\hline $\begin{array}{l}\text { Crassostrea gigas } \\
\text { Portuguese oyster }\end{array}$ & & 2.5 & $\begin{array}{l}\text { (Langston, 2003a). Data } \\
\text { from } 1983 \text {. }\end{array}$ \\
\hline
\end{tabular}

a. converted to DW basis using a FW/DW ratio of 7 for bivalves. 
Table S4. Hg in various biota in comparison with Nereis, Poole Harbour

\begin{tabular}{|c|c|c|c|}
\hline $\mathrm{Hg} \mathrm{mg} \mathrm{kg}^{-1} \mathrm{DW}$ & Holes Bay & $\begin{array}{c}\text { Brownsea/main } \\
\text { harbour }\end{array}$ & Notes \\
\hline \multirow[t]{2}{*}{$\begin{array}{l}\text { Nereis (Hediste) } \\
\text { diversicolor } \\
\text { Ragworm }\end{array}$} & \multicolumn{2}{|c|}{$\begin{array}{l}0.038-0.11 \\
\text { Mean: } 0.076 \\
\text { S.E.: } 0.0068\end{array}$} & $\begin{array}{l}\text { EA supplied data, } 2004 \\
\text { range for Poole Harbour }\end{array}$ \\
\hline & 0.24 & & $\begin{array}{l}\text { Langston et al. unpubl. } \\
\text { Mean over } 25 \text { yr period. }\end{array}$ \\
\hline \multirow[t]{2}{*}{$\begin{array}{l}\text { Scrobicularia plana } \\
\text { Peppery furrow shell }\end{array}$} & 1.08 & & $\begin{array}{l}\text { Langston et al. unpubl. } \\
\text { Mean over } 25 \text { yr period. }\end{array}$ \\
\hline & & 0.14 & $\begin{array}{l}\text { EN supplied data } 2004 \\
\text { Parkstone Bay }\end{array}$ \\
\hline $\begin{array}{l}\text { Mytilus edulis } \\
\text { Common mussel }\end{array}$ & & $0.413^{\mathrm{a}}$ & $\begin{array}{l}\text { (MAFF, 1998) Main } \\
\text { harbour, site not specified. }\end{array}$ \\
\hline $\begin{array}{l}\text { Ostrea edulis } \\
\text { Native oyster }\end{array}$ & 0.49 & 0.16 & $\begin{array}{l}\text { (Langston, 2003a). Data } \\
\text { from } 1983 .\end{array}$ \\
\hline $\begin{array}{l}\text { Crassostrea gigas } \\
\text { Portuguese oyster }\end{array}$ & & 0.26 & $\begin{array}{l}\text { (Langston, 2003a). Data } \\
\text { from } 1983 .\end{array}$ \\
\hline
\end{tabular}

a. converted to DW basis using a FW/DW ratio of 7 for bivalves. 
Table S5. Pb in various biota in comparison with Nereis, Severn Estuary

\begin{tabular}{|c|c|c|c|}
\hline Pb mg kg ${ }^{-1} \mathrm{DW}$ & Avonmouth & Severn Estuary & Notes \\
\hline \multirow[t]{3}{*}{$\begin{array}{l}\text { Nereis (Hediste) } \\
\text { diversicolor } \\
\text { Ragworm }\end{array}$} & \multicolumn{2}{|c|}{$\begin{array}{l}0.55-2.3^{\mathrm{a}} \\
\text { Mean: } 1.51 \\
\text { SE: } 0.32\end{array}$} & $\begin{array}{l}\text { EA supplied data, } 2004 \\
\text { range for Severn Estuary }\end{array}$ \\
\hline & 44.9 & $11.4 ; 17.0$ & $\begin{array}{l}\text { (Ferns and Anderson, } \\
\text { 1997), samples from } \\
1979 / 80\end{array}$ \\
\hline & \multicolumn{2}{|c|}{3.56} & $\begin{array}{l}\text { (Langston et al., } 2003 \mathrm{~b}) \text {. } \\
\text { Mean over } 25 \text { year period }\end{array}$ \\
\hline $\begin{array}{l}\text { Scrobicularia plana } \\
\text { Peppery furrow shell }\end{array}$ & \multicolumn{2}{|c|}{43.5} & $\begin{array}{l}\text { (Langston et al., 2003b). } \\
\text { Mean over } 25 \text { yr period. }\end{array}$ \\
\hline $\begin{array}{l}\text { Mytilus edulis } \\
\text { Common mussel }\end{array}$ & & 10.0 & $\begin{array}{l}\text { Environment Agency, } \\
\text { unpul. res. 2001-05 }\end{array}$ \\
\hline $\begin{array}{l}\text { Macoma balthica } \\
\text { Baltic tellin }\end{array}$ & 40.6 & $19.5-27.5$ & $\begin{array}{l}\text { (Ferns and Anderson, } \\
\text { 1997). Samples from } \\
\text { 1979/80. }\end{array}$ \\
\hline $\begin{array}{l}\text { Nephthys hombergi } \\
\text { Catworm }\end{array}$ & \multicolumn{2}{|c|}{91.9} & $\begin{array}{l}\text { (Ferns and Anderson, } \\
\text { 1997). Samples from } \\
\text { 1979/80. }\end{array}$ \\
\hline $\begin{array}{l}\text { Hydrobia ulva } \\
\text { Laver spire shell }\end{array}$ & \multicolumn{2}{|c|}{44.5} & $\begin{array}{l}\text { (Ferns and Anderson, } \\
\text { 1997). Samples from } \\
\text { 1979/80. }\end{array}$ \\
\hline
\end{tabular}

a. converted to DW basis using a FW/DW ratio of 4.4 for Nereis. 
Table S6. Hg in various biota in comparison with Nereis, Severn Estuary

\begin{tabular}{|l|l|l|}
\hline Hg mg kg $^{-1}$ DW & Severn Estuary & Notes \\
\hline $\begin{array}{l}\text { Nereis (Hediste) } \\
\text { diversicolor } \\
\text { Ragworm }\end{array}$ & $0.08-0.89^{\mathrm{a}}$ & $\begin{array}{l}\text { This study, range for Severn } \\
\text { Estuary }\end{array}$ \\
\cline { 2 - 3 } & 1.42 & $\begin{array}{l}\text { (Langston et al., 2003b). } \\
\text { Mean over 25 yr period. }\end{array}$ \\
\hline $\begin{array}{l}\text { Scrobicularia plana } \\
\text { Peppery furrow shell }\end{array}$ & 0.64 & $\begin{array}{l}\text { (Langston et al., 2003b). } \\
\text { Mean over 25 yr period. }\end{array}$ \\
\hline $\begin{array}{l}\text { Mytilus edulis } \\
\text { Common mussel }\end{array}$ & 0.61 & $\begin{array}{l}\text { (Langston et al., 2003b). Date } \\
\text { not known. } \\
\text { Environment Agency, unpubl. } \\
\text { res., 2001-05 }\end{array}$ \\
\hline
\end{tabular}

a. converted to DW basis using a FW/DW ratio of 4.4 for Nereis. 
Table S7. Summary of avian no observed adverse effect levels (NOAELs) for selected contaminants that were included in the probabilistic risk assessment

\begin{tabular}{|c|c|c|c|c|c|c|}
\hline Metal & Form & Species & $\begin{array}{c}\text { Exposure } \\
\text { Duration (d) }\end{array}$ & Critical Endpoint & $\begin{array}{c}\text { NOAEL } \\
\text { (mg/kg } \\
\text { BW/day) }\end{array}$ & Reference \\
\hline \multirow[t]{4}{*}{$\mathrm{Pb}$} & Lead acetate & $\begin{array}{l}\text { Chicken } \\
\text { (Gallus domesticus) }\end{array}$ & 28 & Egg Production & 1.63 & $\begin{array}{c}\text { (Edens and } \\
\text { Garlich, 1983) }\end{array}$ \\
\hline & Lead acetate & $\begin{array}{l}\text { Japanese quail } \\
(\text { Coturnix c. japonica })\end{array}$ & 84 & Progeny Counts & $0.019^{\mathrm{a}}$ & $\begin{array}{c}\text { Edens and } \\
\text { Garlich, 1983) } \\
\end{array}$ \\
\hline & Lead acetate & $\begin{array}{l}\text { Japanese quail } \\
(\text { Coturnix c. japonica })\end{array}$ & 35 & Egg Production & 0.194 & $\begin{array}{c}\text { (Edens and } \\
\text { Garlich, 1983) } \\
\end{array}$ \\
\hline & Lead acetate & $\begin{array}{l}\text { Japanese quail } \\
\text { (Coturnix c. japonica) }\end{array}$ & 84 & Egg Production & $0.011^{\mathrm{a}}$ & $\begin{array}{c}\text { (Edens et al., } \\
1976)\end{array}$ \\
\hline \multirow[t]{3}{*}{$\mathrm{Hg}$ (inorganic) } & Mercury sulphate & $\begin{array}{l}\text { White leghorn hen } \\
\text { (Gallus domesticus) }\end{array}$ & 21 & Egg hatchability & 5.5 & (Scott, 1977) \\
\hline & Mercuric chloride & $\begin{array}{l}\text { Japanese quail } \\
(\text { Coturnix c. japonica })\end{array}$ & 140 & Egg Production & 0.45 & $\begin{array}{c}\text { (Hill and } \\
\text { Shaffner, 1976) }\end{array}$ \\
\hline & Mercuric chloride & $\begin{array}{l}\text { Japanese quail } \\
\text { (Coturnix c. japonica) }\end{array}$ & N/A & Mortality & $0.30^{\mathrm{b}}$ & $\begin{array}{c}\text { (Hill and Soares, } \\
1984)\end{array}$ \\
\hline \multirow[t]{9}{*}{$\mathrm{Hg}$ (organic) } & Methyl mercury chloride & $\begin{array}{l}\text { Great Egret } \\
(\text { Ardea albus })\end{array}$ & 91 & Growth & 0.0038 & $\begin{array}{c}\text { (Spalding et al., } \\
2000)\end{array}$ \\
\hline & Methyl mercury chloride & $\begin{array}{l}\text { Great Egret } \\
\text { (Ardea albus) }\end{array}$ & 91 & Growth & 0.0108 & $\begin{array}{c}\text { (Spalding et al., } \\
2000)\end{array}$ \\
\hline & $\begin{array}{l}\text { Methyl mercury } \\
\text { dicyandiamide }\end{array}$ & $\begin{array}{l}\text { Mallard } \\
\text { (Anas platyrhynchos) }\end{array}$ & $>365$ & $\begin{array}{l}\text { Egg and Duckling } \\
\text { Production }\end{array}$ & $0.0064^{\mathrm{a}}$ & (Heinz, 1979) \\
\hline & $\begin{array}{l}\text { Methyl mercury } \\
\text { dicyandiamide }\end{array}$ & $\begin{array}{l}\text { Mallard } \\
\text { (Anas platyrhynchos) }\end{array}$ & N/A & Mortality & $0.289^{b}$ & $\begin{array}{c}\text { (Hudson et al., } \\
1984) \\
\end{array}$ \\
\hline & Methyl mercury & $\begin{array}{l}\text { Bobwhite quail } \\
\text { (Colinus virginianus) }\end{array}$ & N/A & Mortality & $0.239^{\mathrm{b}}$ & $\begin{array}{c}\text { (Hudson et al., } \\
1984) \\
\end{array}$ \\
\hline & Methyl mercury & $\begin{array}{l}\text { Japanese quail } \\
\text { (Coturnix c. japonica) }\end{array}$ & N/A & Mortality & $0.195^{\mathrm{b}}$ & $\begin{array}{c}\text { (Hill and Soares, } \\
\text { 1984; Hudson et } \\
\text { al., 1984) }\end{array}$ \\
\hline & Methyl mercury & $\begin{array}{l}\text { Fulvous whistling duck } \\
\text { (Dendrocygna bicolour) }\end{array}$ & N/A & Mortality & $0.378^{\mathrm{b}}$ & $\begin{array}{c}\text { (Hudson et al., } \\
\text { 1984) } \\
\end{array}$ \\
\hline & $\begin{array}{l}\text { Methyl mercury } \\
\text { dicyandiamide }\end{array}$ & $\begin{array}{l}\text { House sparrow } \\
\text { (Passer domesticus) }\end{array}$ & N/A & Mortality & $0.219^{b}$ & $\begin{array}{c}\text { (Hudson et al., } \\
1984 \text { ) }\end{array}$ \\
\hline & $\begin{array}{l}\text { Methyl mercury } \\
\text { dicyandiamide }\end{array}$ & $\begin{array}{l}\text { Pheasant } \\
\text { (Phasianus colchicus) }\end{array}$ & N/A & Mortality & $0.253^{\mathrm{b}}$ & $\begin{array}{c}\text { (Hudson et al., } \\
1984)\end{array}$ \\
\hline
\end{tabular}

a. values based on a LOAEL divided by a factor of 10; b. values based on a LD50 value divided by a factor of 100. N/A indicates that duration of exposure is not applicable as single oral dose was used. 


\section{References for Supplementary Material}

Boyden CR. Distribution of some trace metals in Poole Harbour, Dorset. Marine Pollution Bulletin 1975; 6: 180-187.

Cain BW, Pafford EA. Effects of dietary nickel on survival and growth of Mallard ducklings. Archives of Environmental Contamination and Toxicology 1981; 10: 737-745.

Dahlgren RB, Linder RL, Carlson CW. Polychlorinated biphenyls: their effects on penned pheasants. Environmental Health Perspectives 1972; 1: 89-101.

Edens FW, Benton E, Bursian SJ, Morgan GW. Effect of Dietary Lead on ReproductivePerformance in Japanese Quail, Coturnix-Coturnix Japonica. Toxicology and Applied Pharmacology 1976; 38: 307-314.

Edens FW, Garlich JD. Lead-Induced Egg-Production Decrease in Leghorn and Japanese Quail Hens. Poultry Science 1983; 62: 1757-1763.

Ferns PN, Anderson JI. Lead in the diet and body tissues of dunlins Calidris alpina from the Bristol Channel, UK. Environmental Pollution 1997; 96: 35-42.

Heinz GH. Methyl mercury: reproductive and behavioral effects on three generations of mallard ducks. Journal of Wildlife Management 1979; 43: 394-401.

Heinz GH, Hoffman DJ, Krynitsky AJ, Weller DMG. Reproduction in Mallards Fed Selenium. Environmental Toxicology and Chemistry 1987; 6: 423-433.

Hill EF, Shaffner CS. Sexual maturation and productivity of japanese quaiol fed graded concentrations of mercuric chloride. Poultry Science 1976; 55: 1449-1459.

Hill EF, Soares JH. Subchronic Mercury Exposure in Coturnix and a Method of Hazard Evaluation. Environmental Toxicology and Chemistry 1984; 3: 489-502.

Hough JL, Baird MB, Sfeir GT, Pacini CS, Darrow D, Wheelock C. Benzo(a)Pyrene Enhances Atherosclerosis in White Carneau and Show Racer Pigeons. Arteriosclerosis and Thrombosis 1993; 13: 1721-1727.

Hudson RH, Tucker RK, Haegele MA. Handbook of toxicity of pesticides to wildlife. USDI Fish and Wildlife Service, Washington, D C, 1984.

Langston WJ, Chesman BS, Burt GR, Hawkins SJ, Readman J, Worsfold P. Characterisation of the South West European Marine Sites: The Severn Estuary pSAC, SPA. . Occasional Publications of the MBA No. 13. 13. Marine Biological Association, Plymouth, 2003b.

Langston WJ, Chesman, B.S., Burt, G.R., Hawkins, S.J., Readman, J., Worsfold, P. . Characterisation of the South West European Marine Sites: Poole Harbour SPA. Occasional Publications of the MBA No. 12. Marine Biological Association, Plymouth, 2003a.

Laskey JW, Edens FW. Effects of chronic high-level manganese exposure on male behavior in the Japanese Quail (Cotirnix coturnix japonica). Poultry Science 1985; 64: 579584.

MAFF. Concentrations of metals and other elements in marine fish and shellfish. Food Surveillance Data Sheet 151. Ministry of Agriculture Fisheries and Food, London, 1998.

Mehring ALJ, Brumbaugh JH, Sutherland AJ, Titus HW. The tolerance of growing chickens for dietary copper. Poultry Science 1960; 39: 713-719.

Romoser GL, Dudley WA, Machlin LJ, Loveless L. Toxicity of vanadium and chromium for the growing chick. Poultry Science 1961; 40: 1171-1173.

Sample BE, Opresko DM, Suter II GW. Toxicological Benchmarks for Wildlife: 1996 Revision. Oak Ridge National Laboratory, Oak Ridge, TN., 1997, pp. 217. 
Schlatterer B, Coenen TMM, Ebert E, Grau R, Hilbig V, Munk R. Effects of Bis(tri nbutyltin) oxide in Japanese Quail exposed during egg laying period: an interlaboratory comparison study. Archives of Environmental Contamination and Toxicology 1993; 24: 440-448.

Scott ML. Effects of Pcbs, Ddt, and Mercury-Compounds in Chickens and Japanese Quail. Federation Proceedings 1977; 36: 1888-1893.

Spalding MG, Frederick PC, McGill HC, Bouton SN, McDowell LR. Methylmercury accumulation in tissues and its effects on growth and appetite in captive great egrets. Journal of Wildlife Diseases 2000; 36: 411-422.

Stanley TR, Spann JW, Smith GJ, Rosscoe R. Main and Interactive Effects of Arsenic and Selenium on Mallard Reproduction and Duckling Growth and Survival. Archives of Environmental Contamination and Toxicology 1994; 26: 444-451.

U.S. Environmental Protection Agency. ECOTOXicology Database System. Office of Research and Development,, U.S. Environmental Protection Agency, 2002.

White DH, Finley MT. Uptake and retention of dietary cadmium in mallard ducks.

Environment Research 1978; 17: 53-59. 